\title{
Immigration policy mismatches and counterproductive outcomes: unauthorized migration to the U.S. in two eras
}

\author{
Douglas S. Massey(D)
}

Correspondence: dmassey@ princeton.edu

Princeton University, Princeton, NJ, USA

\begin{abstract}
The world appears to be moving into a new era of international migration during which gaps between policies needed to manage migratory flows and those enacted in practice will widen. Whereas immigrants in the late 20th century were motivated by a desire to improve their wellbeing by accessing opportunities in richer countries, in the early 21st century they are increasingly motivated by a desire to escape threats at places of origin, yielding very different patterns of migration and selectivity. Using the United States as an example, this paper reviews how mismatches between the underlying realities of international migration and the policies adopted to manage them, in both eras have produced and continue to produce dysfunctional outcomes. Although deleterious policy outcomes might be avoided in the future by combining a well-grounded conceptual understanding of the forces producing immigration with a clear statement of the goals to be achieved through specific policy interventions, the avoidance of further dysfunctional outcomes is unlikely to be achieved in an age of rising populism, disinformation, and xenophobia.
\end{abstract}

Keywords: Migration, Refugees, Asylees, Climate change, Violence, Immigration policy

Despite the prominence of international migration throughout the world, its causes and consequences are poorly understood by policy makers and the public. Both sectors give little thought to the macro- and micro-level processes that undergird international population movements, or how they might be managed to minimize the costs and maximize the benefits for all concerned. Instead they react emotionally to the new arrivals without any real understanding of how they affect existing social and economic circumstances. Although human beings are naturally predisposed to accept and trust others (see Fiske 2014), processes of acceptance and integration take time and this reality yields a temporal gap during which natives are wary and unsure of immigrants' intentions and effects on the social order (Ramos et al. 2019). The resulting void of understanding tempts powerful actors in society to fill it by framing immigrants as a threat in order to mobilize resources for their benefit (Meyers 2007).

(c) The Author(s). 2020 Open Access This article is licensed under a Creative Commons Attribution 4.0 International License, which permits use, sharing, adaptation, distribution and reproduction in any medium or format, as long as you give appropriate credit to the original author(s) and the source, provide a link to the Creative Commons licence, and indicate if changes were made. The images or other third party material in this article are included in the article's Creative Commons licence, unless indicated otherwise in a credit line to the material. If material is not included in the article's Creative Commons licence and your intended use is not permitted by statutory regulation or exceeds the permitted use, you will need to obtain permission directly from the copyright holder. To view a copy of this licence, visit http://creativecommons.org/licenses/by/4.0/. 
People are naturally homophilic and seek to affiliate and interact with others like them (McPherson et al. 2001). Whenever humans encounter unfamiliar social others, they seek to categorize them along two basic dimensions to make sense of their intentions and abilities (Fiske et al. 2002). With respect to intentions, people are primed to learn whether the motivations of others are hostile or benevolent, whether they are to be trusted and embraced or suspected and avoided. Whatever their intentions, it is also important to judge the ability of unknown others to act on their motivations, assessing the degree to which they are capable of getting things done.

These two dimensions of social perception are labeled warmth and competence and together they define a space in human social cognition described by the stereotype content model (Cuddy et al. 2008). People perceived as high in both warmth and competence comprise the ingroup. Other combinations of warmth and competence yield three distinct kinds of outgroups. People perceived as low in warmth and high in competence represent envied outgroups. Under normal circumstances, they are shown deference but not necessarily liked. Examples include technocrats, the rich, and the powerful. The coincidence of high warmth and low competence defines pitied outgroups, such as the elderly, the infirm, and the disabled. Finally, the combination of low warmth and low competence yields despised outgroups whose members are objects of contempt and disgust, such as the homeless, drug addicts, and criminals (Fiske et al. 2007).

The social position of any group within this two-dimensional cognitive space is not fixed, but malleable, varying across time, space, and cultures (Cuddy et al. 2009). A group's position is established through quotidian interactions between group members that over time reify categorical boundaries and assign categorical attributes to social groups (Lamont and Molnar 2002). Categorical boundaries and meanings can also be influence strongly through the rhetoric of powerful social actors. Whenever immigrants enter a society, they are vulnerable to the framing actions of persons wielding power and influence-politicians, pundits, and media personalities-who wield undue influence on the context of reception within which immigrants must adapt and integrate (Portes and Zhou 1993).

The social construction of group boundaries and identities is also strongly affected by economic circumstances, with hardening boundaries, negative framings, and misanthropic attributions tending to prevail during periods of economic inequality and insecurity (Goldin 1994; Timmer and Williamson 1998; Meyers 2007). Whenever periods of economic instability coincide with periods of rapid demographic change through immigration, powerful political actors acquire a self-interest in pandering to popular feelings of vulnerability and doubt by framing immigrants as a threat to natives' social standing, economic security, and cultural dominance (Massey et al. 2016). Fear is a well-established tool for political mobilization (Robin 2006) and throughout history it has proved difficult for politicians, pundits, and bureaucrats to resist the temptation to cultivate fear of outsiders in order to achieve self-serving goals (Higham 1981; Daniels 2004).

By fostering nativism, prejudice, and xenophobia, politicians can win elections, intellectuals can sell books, pundits can garner media airtime, and bureaucrats can accumulate institutional power (Massey et al. 2016). Immigration and border policies then evolve to serve the self-interests of a small set of privileged social actors. Facts, rational 
analysis, and scientific understandings are marginalized in public debates as political entrepreneurs vie to situate immigrants within unfavorable quadrants of natives' social cognition, framing groups as envied outgroups to be resented (Asians and Jews) or as despised outgroups to be excluded (Hispanics, Muslims, and Africans-see Lee and Fiske 2006).

When political decisions are made under the influence of such framings, the end result is a harsh mismatch between the policies that are enacted and those needed to minimize the costs and maximize the benefits of immigration for society as a whole. Such was the case in the United States during the final decades of the $20^{\text {th }}$ century when policies based on anti-immigrant sentiments and racial animus were implemented to block the flow of undocumented Mexicans into the United States. These policies were not grounded in any real understanding of the causes or consequences of Mexican immigration, however, and rather than achieving their intended goal of curtailing unauthorized migration, they backfired and accelerated the rate of undocumented population growth (see Massey et al. 2016).

In the early $21^{\text {st }}$ century, the American immigration landscape has radically changed, with mass Mexican migration coming to an end and being replaced by a much smaller flow of Central Americans. As in the late $20^{\text {th }}$ century, however, the realities of this new immigration are poorly understood by policy makers and the public, resulting in much public posturing and invidious portrayals to create yet another policy mismatch, one with alarming humanitarian consequences. Unlike Mexicans, Central Americans arriving at the southern U.S. border today are not seeking not employment but refuge. Yet both Obama and Trump have framed the cross-border migration not as a humanitarian challenge but as an enforcement issue to be addressed by detention and deportation rather than assistance and succor.

\section{Late $20^{\text {th }}$ century mismatches}

U.S. immigration policies implemented in the late $20^{\text {th }}$ century rested on a profound misreading of the underlying dynamics of immigration. During that epoch, international migration grew rapidly throughout the world as individuals sought opportunities for more productive employment and higher incomes outside their countries of birth. From 1975 to 2000, the global stock of international migrants rose from 78.4 million to 172.3 million persons and their share of the world's population rose from 1.92 to $2.83 \%$. This surge in immigration was part and parcel of a broader process of economic globalization that unfolded in the late $20^{\text {th }}$ century. During this time, goods, commodities, capital, and services moved across international borders with increasing frequency, along with workers offering labor and human capital to global employers.

In order to understand these new patterns and processes of international movement, the International Union for the Scientific Study of Population in 1991 empaneled a Committee on South-North Migration. Its charge was to review prevailing theories of international migration, evaluate their performance empirically, and draw on this evaluation to construct a synthetic theoretical model capable of accounting for the patterns of international migration then prevailing throughout the world (see Massey et al. 1998).

The resulting synthetic vision began by theorizing the demand for migrant labor, which was seen as originating in the globalization of factor markets (see Hatton and 
Williamson 1998) and the structural segmentation of labor markets within advanced economies (Piore 1979). On the supply side, a ready stock of workers was created by structural transformations experienced in developing nations as they entered the global market economy (Portes and Walton 1981). The ensuing shifts from agrarian to industrial production (or from command to market mechanisms) inevitably displaced large numbers of people from traditional livelihoods (Sassen 1988). Households then responded to these macro-structural forces through migration, sending out workers for employment in national and international markets (Massey 1988).

These migrants were motivated to maximize income (Todaro 1976) and/or manage risks (Stark 1991) on behalf of the household. Labor flows were also facilitated by the deliberate recruitment of foreign workers by employers in high-wage countries (Piore 1979). Once began, however, migratory flows tended to persist and expand as global market forces created new links of transportation and communication within and between nations (Sassen 1988) and as migrant networks evolved to generate stocks of social capital that reduced the costs and risks of further international movement (Massey 1990).

Initially, movements between nations tended to be circular, with people moving back and forth between origin and destination areas on a regular basis given the legal, cultural, and linguistic obstacles to settlement in a foreign land. Moving repeatedly back and forth between sending and receiving nations, migrants were able to generate remittances that both diversified and increased household incomes, thereby overcoming liquidity constraints on consumption and investment (Taylor 1986). Although temporary labor migration is most closely associated with the New Economics of Labor Migration (Massey et al. 1998), it is by no means inconsistent with neoclassical economics under a variety of circumstances, such as when foreign earnings have greater purchasing power at home than abroad, when working abroad leads to little accumulation of skills useful in destination areas, or when migrants prefer spending at home rather than abroad (Dustmann and Görlach 2016).

As long as the costs and risks of cross-border movement remained low, the transnational circulation of international migrants tended to continue with relatively low rates of settlement in both Europe (Martin and Miller 1980) and the United States (Calavita 1992). However, when governmental policies were imposed to curtail wellestablished circular flows through repressive police actions, processes of settlement accelerated (Reichert and Massey 1982). As a result, when European nations cancelled guest worker programs and ended labor recruitment in the wake of the 1973 global recession, circular migration stopped and migrant workers instead began to dig in and petition for the entry of family members from abroad causing immigration populations to grow rather than shrink (Martin and Miller 1980).

Much the same happened in the United States, though it took somewhat longer to play out (Massey et al. 2002). Although the U.S. Congress cancelled a temporary worker agreement with Mexico known as the Bracero Program at the end of 1964, settlement did not immediately ensue. Instead former Bracero migrants continued to circulate under undocumented auspices (Massey and Liang 1989). It was not until 1986, when aggressive border enforcement efforts began to curtail return migration that undocumented migrants began to settled north of the border, leading to the rapid expansion of the unauthorized population (Massey et al. 2016). 
In both cases, the shift from circulation to settlement followed misdiagnoses of the policy challenge at hand. After the 1970s, leaders in both the U.S. and Europe had come to perceive labor migration as a threat to social stability and economic wellbeing rather than a natural outgrowth of the integration of markets across international boundaries (Massey 2013). Given this diagnosis, the policies they implemented sought to curtail rather than manage the migratory flows, yielding a policy mismatch that ultimately backfired and led to the accelerated growth of foreign populations, especially in the United States.

As indicated by the solid line in Fig. 1, which draws on data from the World Bank (2019), the immigrant population of the Eurozone grew linearly at a slow rate through the 1970s and then suddenly accelerated between 1985 and 1990 and moved upward again after the year 2000, as circulating workers were replaced by long-term settlers who sponsored the entry of family members from abroad. In contrast, circular undocumented migration continued well after the U.S. cancelled the Bracero Program. From 1965 to1985, 85\% of undocumented entries were offset by departures (Massey and Singer 1995) and the undocumented population grew slowly, with a notable drop from 1986 to 1988 owing to regularization under the 1986 Immigration Reform and Control Act.

Thereafter, however, the initiation of two intensive border enforcement efforts (Operation Blockade in El Paso in 1993 and Operation Gatekeeper in San Diego in 1994) and their subsequent extension to other sectors along the border dramatically increased the costs and risks of unauthorized border crossing. The effect of these increases was not to deter undocumented migration into the United States, however, but to reduce the rate of return migration back to Mexico (Massey et al. 2016). After experiencing the rising costs and risks of undocumented border crossing, migrants were loath to return home and face doing it again the following year (Massey et al. 2016). Instead, migrants

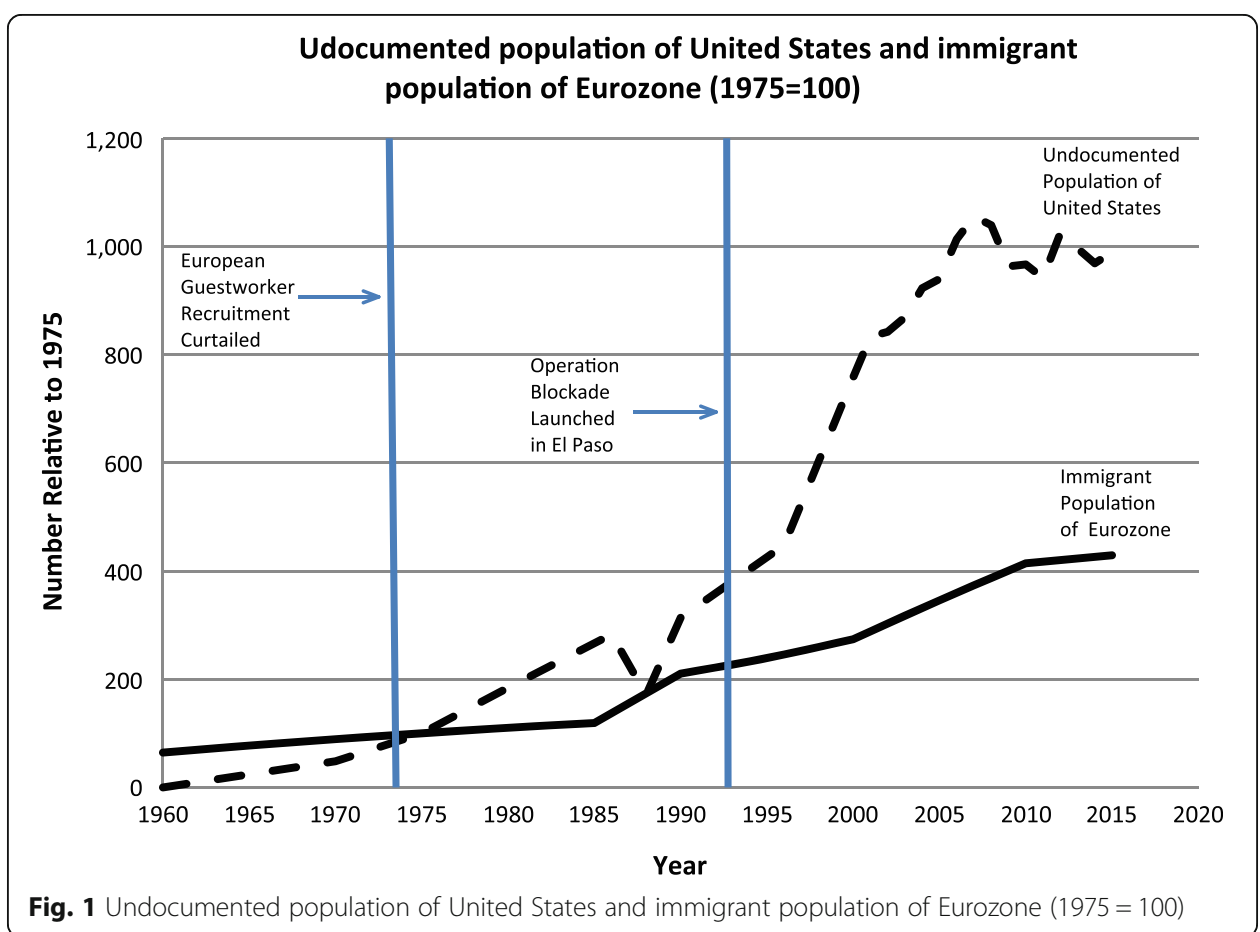


began to stay longer and as they did so, to send for family members to join them, bringing about a sharp acceleration in undocumented population growth between 1996 and 2001, as shown by the dashed line in Fig. 1 (which draws on data compiled by Wasem 2011 and Passel and Cohn 2018). The ensuing section describes this policy failure in some detail.

\section{The U.S. policy mismatch: 1965-2006}

In practical terms, the United States supported two temporary labor programs during the postwar period: a de jure program based on the legal circulation of Bracero migrants from 1942 to 1965 and a de facto program based on the relatively free but unauthorized circulation of migrants between 1965 and 1985 (Massey et al. 2002). Figure 2 shows Mexican migration to the United States in three legal statuses from 1940 to the present (drawing on data from the U.S. Department of Homeland Security and the U.S. Immigration and Naturalization Service). Entries by documented migrants (the solid line) and legal temporary workers (the dashed line) come directly from the U.S. Office of Immigration Statistics' Yearbook of Immigration Statistics (U.S. Department of Homeland Security 2020) and undocumented entries (the dotted line) are proxied by an index that divides the number of border apprehensions by the number of Border Patrol officers (from U.S. Customs and Border Protection 2019), thereby providing a rough control for temporal changes in the enforcement effort.

Bracero migration began in 1942 and remained small throughout the Second World War. When the U.S. Congress scaled back the Bracero Program after 1945 undocumented migration rose, prompting Congress to expand it between 1947 and 1949. Another cutback followed in 1950, however, which prompted yet another surge in undocumented migration that was then met with another expansion of Bracero migration between 1950 and 1951. However, the latter expansion was still insufficient to

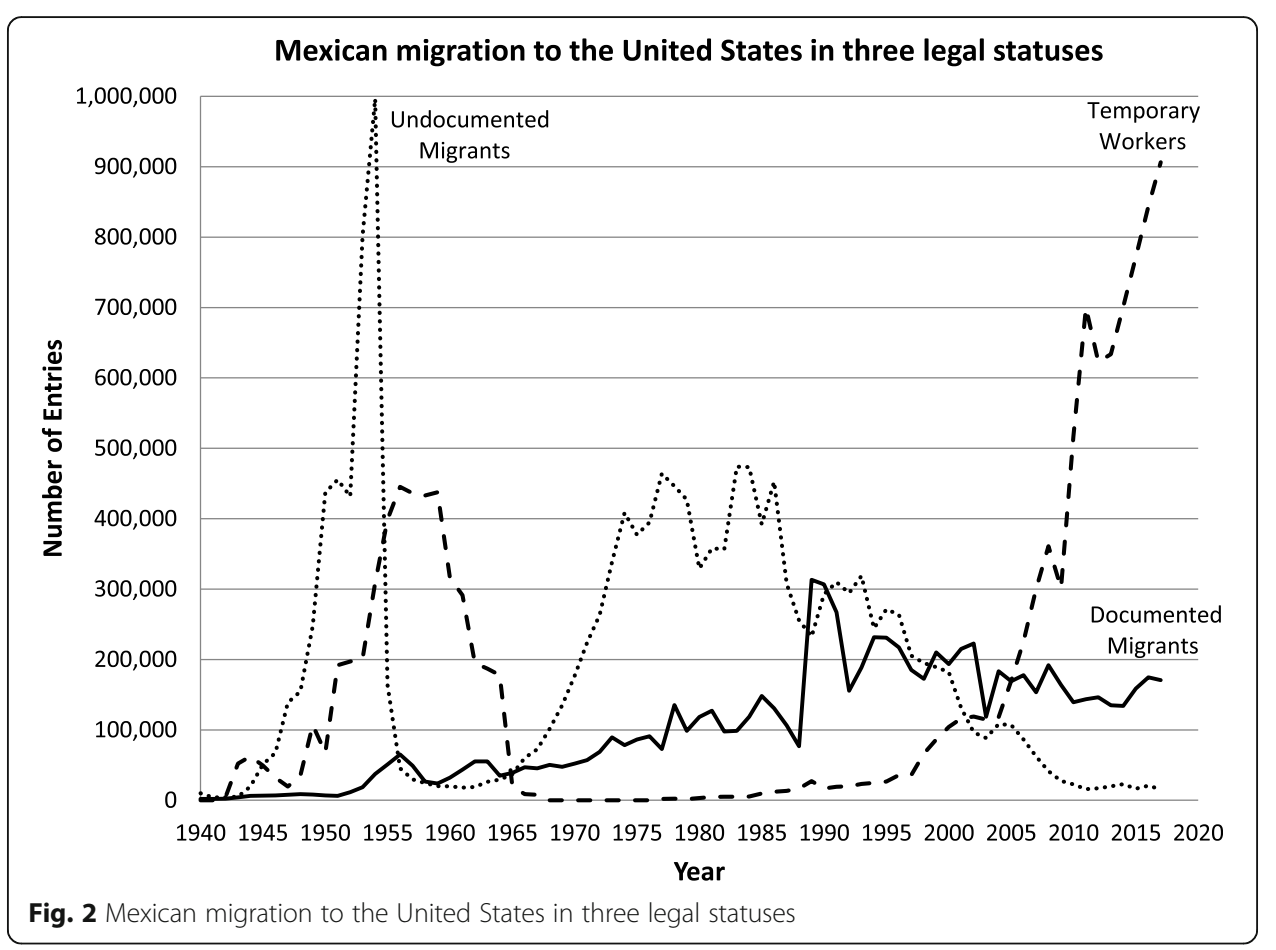


satisfy U.S. labor demand and undocumented migration continued to rise. The surge in unauthorized border crossings triggered an anti-immigrant reaction and full-scale militarization of the Mexico-U.S. border in 1953-1954 known as Operation Wetback (Calavita 1992). At the same time, however, Congress quietly expanded the Bracero Program which grew from around 200,000 entries in 1953 to nearly 450,000 in 1956, and this expansion finally met the demand for labor. As a result, undocumented migration fell sharply and remained low through 1965 (Massey et al. 2002).

In early 1965, the U.S. Congress acted to place the first-ever numerical limits on legal immigration from the Western Hemisphere; and in 1976 it capped immigration from the Americas at 20,000 persons per country per year. The sudden curtailment of opportunities for legal entry spurred a sharp increase in undocumented migration from 1965 to 1977 (Massey and Pren 2012a). Documented migration also increased, moving beyond the 20,000-visa cap because immediate relatives of U.S. citizens were not subject to the numerical limitation. After 1977, however, the inflow of undocumented migrants stabilized and began to decline after 1986. Following a short revival during the early 1990 s undocumented migration fell steadily to reach very low levels by 2010 , as temporary worker migration surged and legal permanent immigration continued apace.

Whereas the circular movement of Bracero migrants had been largely invisible to U.S. natives, the circular movement of undocumented migrants was increasingly visible as border apprehensions rose. In practical terms little had changed before and after 1965. The same migrants were leaving the same communities for the same U.S. worksites and generally earning the same wages as legal residents and citizens working in the same labor markets (Massey and Gentsch 2014). In one key way, however, much had changed, for now the migrants were "illegal" and thus by definition "criminals" and "lawbreakers" who could be framed by politicians, pundits, and entrepreneurial bureaucrats as a grave threat to the nation (Massey et al. 2014).

After 1965, undocumented migration was increasingly framed as a "crisis" in the media and in public debates, portrayed either as a "flood" or "ivasion" (Massey et al. 2002). Figure 3 draws on data from Massey and Pren (2012b) to plot the number of times the terms illegal, undocumented, or unauthorized were paired with Mexico or Mexican immigrants and the words crisis, flood, or invasion each year from 1965 through 1995 (smoothed using three-year moving averages), expressed as a function of the annual number of apprehensions (in thousands). The strong relationship between the two data series is indicated by a simple linear regression equation in which apprehensions explain almost $70 \%$ of the yearly variation in the frequency of crisis metaphors, which fueled a steady rise in what Chavez (2008) has called the "Latino threat narrative."

This narrative pushed public opinion steadily in a more conservative direction, as shown in Fig. 4 which uses data from Massey and Pren (2012a) to show the percentage of U.S. adults who identified as conservatives, expressed as a function of border apprehensions from 1965 to 1995, yielding an R-squared of 0.94. Rising conservatism prompted policy makers to enact ever stricter immigration laws and harsher enforcement border operations that ultimately resulted in an unprecedented militarization of the Mexico-U.S. border (Massey and Pren 2012a).

Figure 5 illustrates the degree of the mismatch between the U.S. border enforcement effort and the actual volume of undocumented migration by plotting the real value of the Border Patrol's budget (in 2018 U.S. dollars) from 1965 to the present (using data 


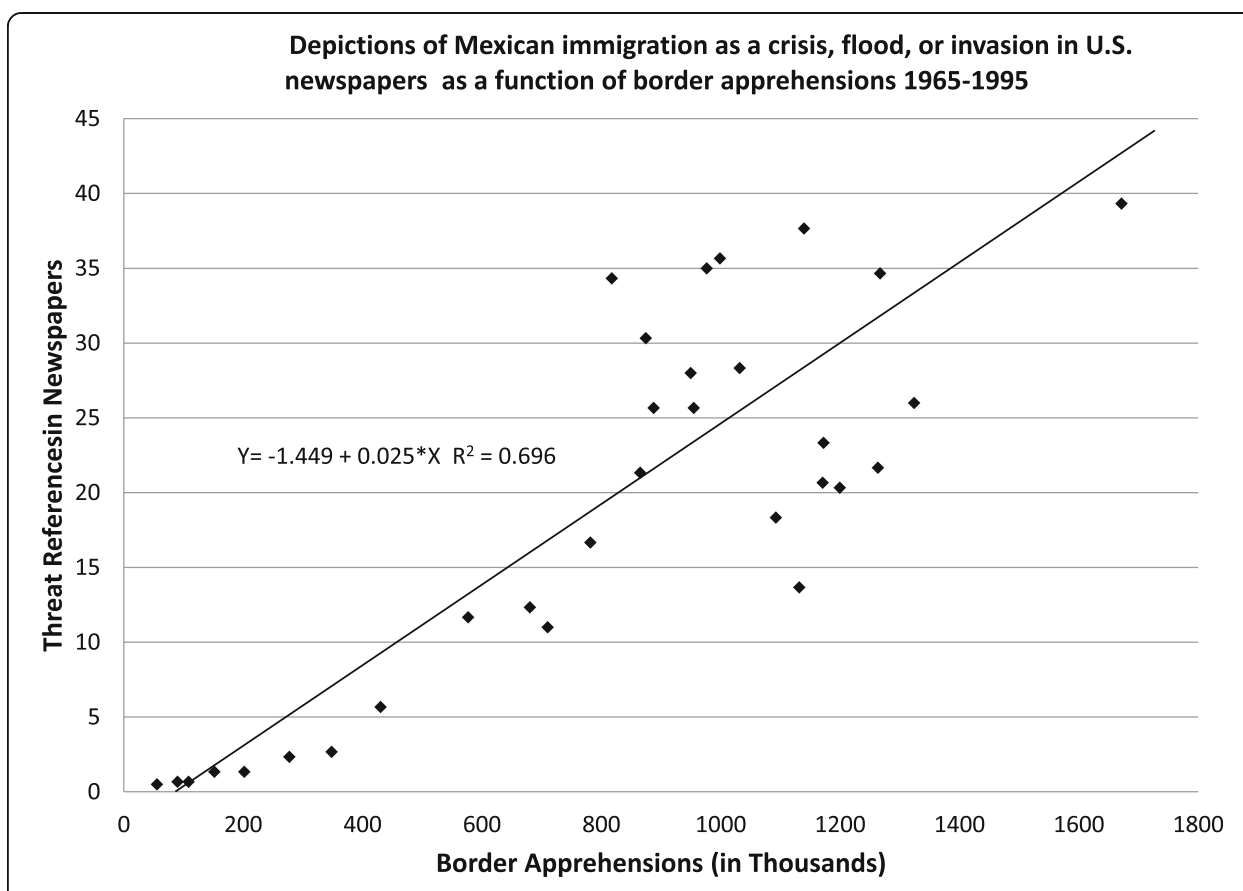

Fig. 3 Depictions of Mexican immigration as a crisis, flood, or invasion in U.S. newspapers as a function of border apprehensions 1965-1995

from U.S. Customs and Border Enforcement 2019). The budget began to rise in 1986 (even though undocumented migration had stabilized back in 1979). It then accelerated in 1995 (about when undocumented migration began to decline) and then went on to expand exponentially after 2006 (when net undocumented migration from Mexico was turning negative). The enforcement budget today fluctuates around $\$ 4$ billion per year

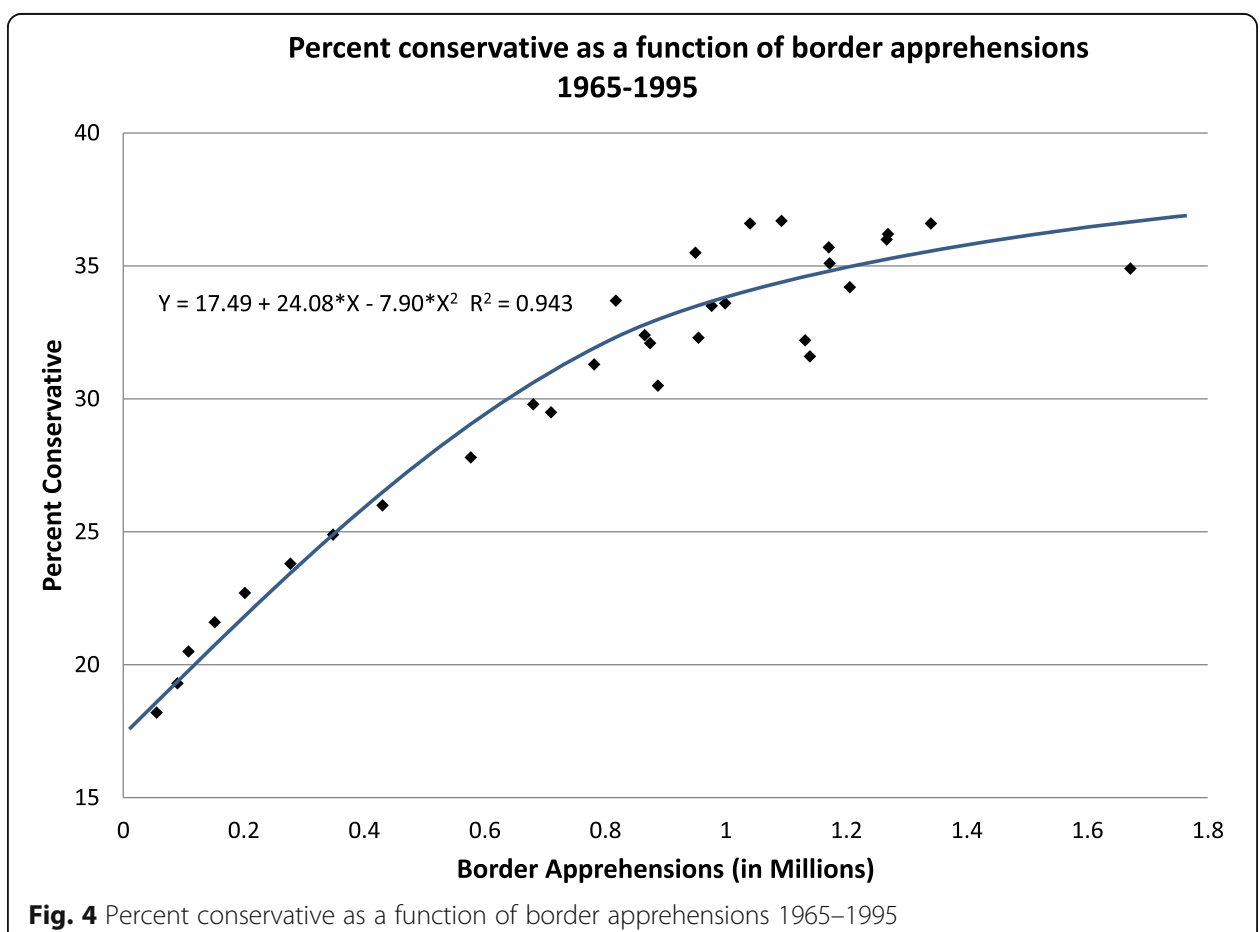




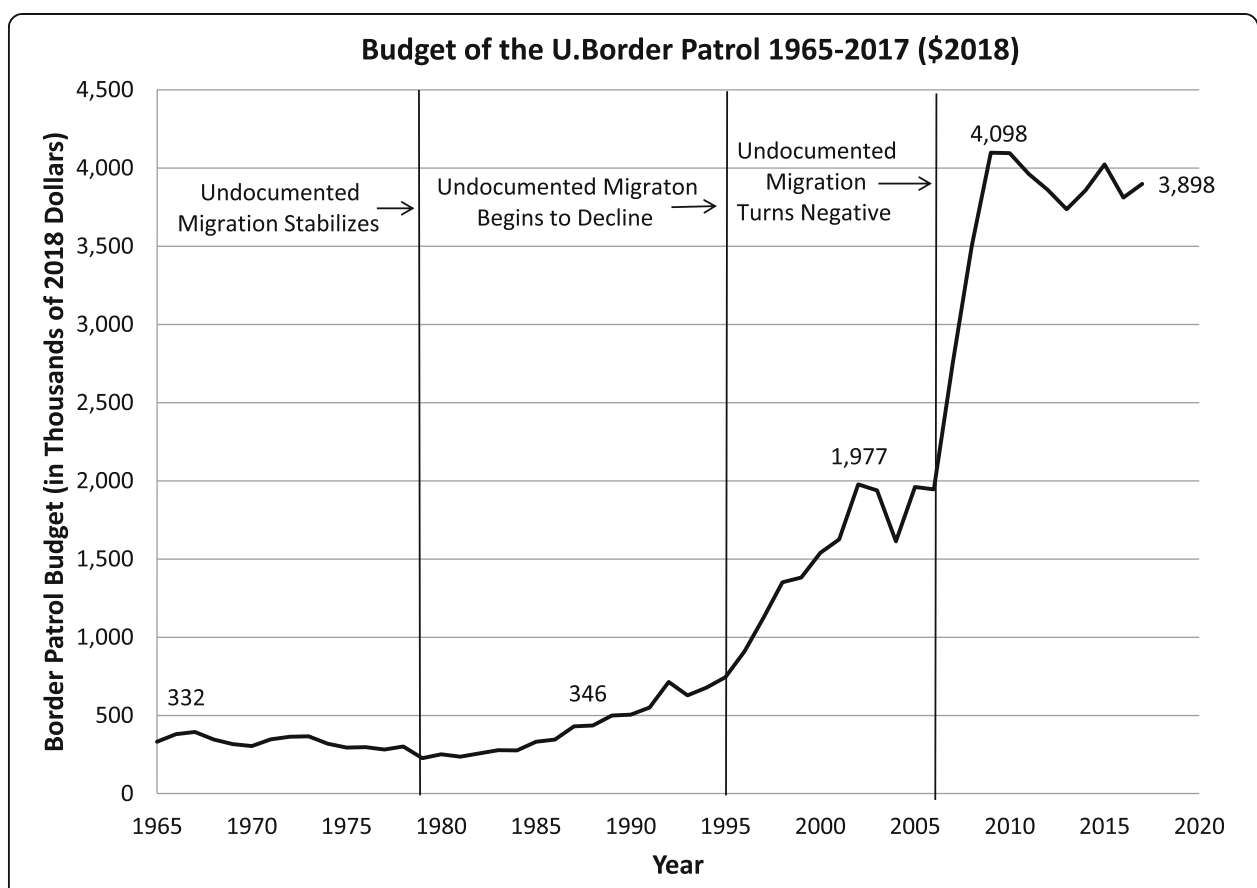

Fig. 5 Budget of the U. Border Patrol 1965-2017 (\$2018)

despite the fact that net undocumented migration from Mexico has been zero or negative since 2007.

The unprecedented militarization of the border had profound effects on patterns and processes of undocumented migration, though they were not the outcomes expected by officials in the Clinton Administration. Figure 6 draws upon latest data from the

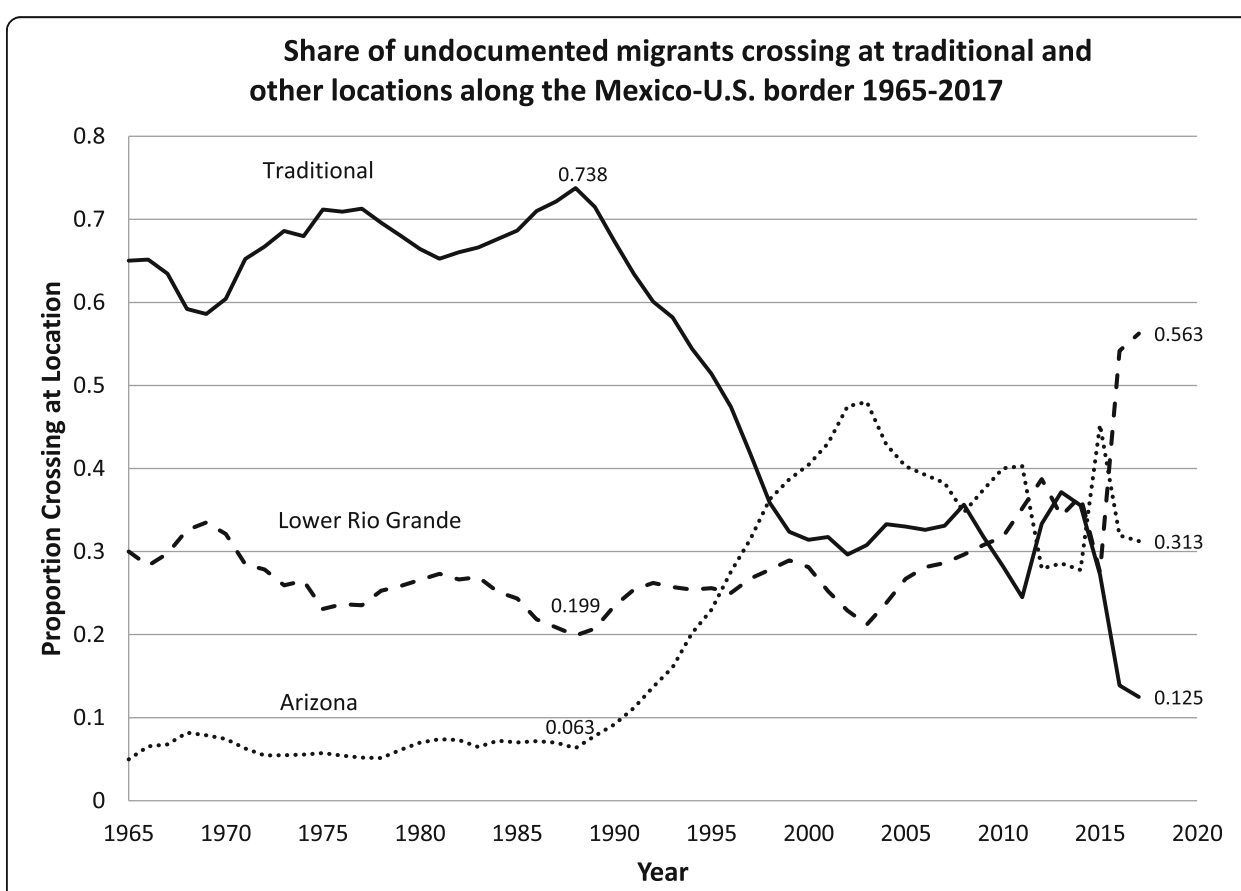

Fig. 6 Share of undocumented migrants crossing at traditional and other locations along the Mexico-U.S. border 1965-2017 
Mexican Migration Project (MMP170) to plot changes over time in the place of unauthorized border crossing. The MMP database consists of representative samples of 170 Mexican surveyed between the years 1987 and 2018, combined with snowball samples of migrants from these same communities interviewed in the United States. The resulting data have been validated against nationally representative surveys and shown to provide an accurate profile of patterns and processes of both documented and undocumented movement (see Massey and Zenteno 2000; Massey and Capoferro 2004).

From 1965 to 1988 the large majority of undocumented migrants (74\% at the latter date) crossed at traditional points along the border near San Diego and El Paso. Thereafter the share crossing at these two locations plummeted to reach a local minimum of around 30\% while the share crossing into Arizona rose to around 48\%). By 2017 the share crossing at traditional locations had fallen to around $12.5 \%$ as the percentage crossing at other points (in the lower Rio Grande Valley as well Arizona) rose to 56\%.

The shift of border crossing away from urbanized areas of San Diego and El Paso and into remote portions of the Sonoran Desert or the lower Rio Grande Valley dramatically increased the costs and risks of unauthorized border crossing. Figure 7 draws on the MMP data to show temporal changes in the cost (in 2018 U.S. dollars) of unauthorized border crossing. From an average of \$1773 in 1965 the amount fell to $\$ 854$ in 1985 as migration became a routinized process supported by strong social networks (see Singer and Massey 1998). Beginning with the passage of the Immigration Control and Reform Act (IRCA) in 1986, however, and continuing through the launching the border blockades in El Paso and San Diego in 1993 and 1994 and the passage of the USA PATRIOT Act in 2001, the border was steadily militarized and the cost of crossing steadily rose to reach $\$ 7002$ in 2017 , an increase of $820 \%$ since 1985 . The correlation between the real value of the Border Patrol's budget and the real cost of border crossing is 0.91 .

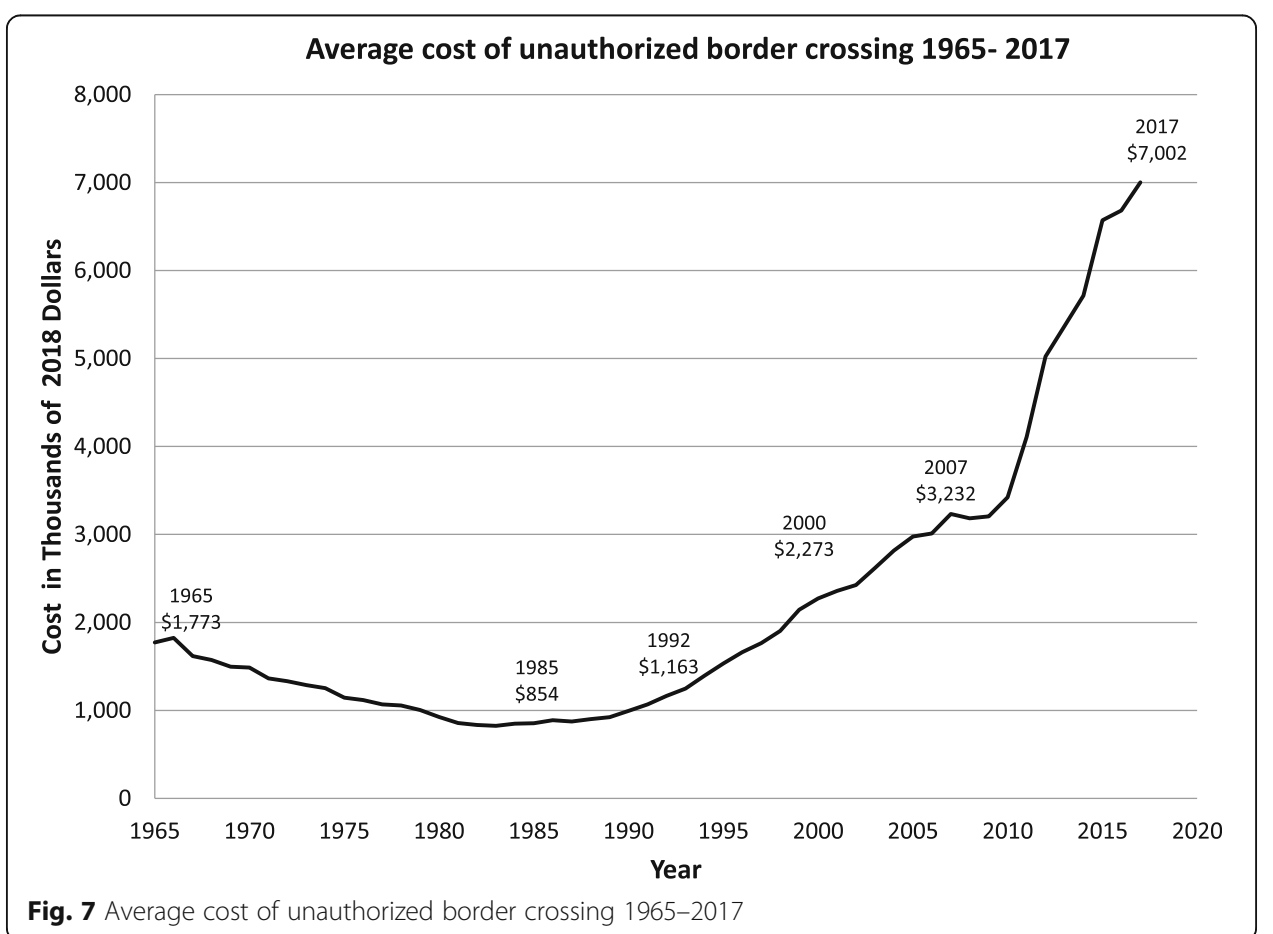


Although the cost of border crossing began to rise immediately after IRCA's 1986 passage (which made crossing in traditional locations more difficult), the death rate did not increase until Operation Blockade in 1993 and Operation Gatekeeper in 1994 diverted flows into more hazardous territory. Figure 8 combines data from Eschbach et al. (2001) and U.S. Customs and Border Protection (2018) to plot the number of deaths recorded along the Mexico-U.S. border from 1985 through 2017. From 1985 to 1993, the number of deaths fell from 1947 to 67, but thereafter mortality along the border increased, rising to 492 in 2005 before falling to 251 in 2015 and finishing at 294 in 2017. The correlation between the real value of the Border Patrol budget and the number of border deaths is 0.75 . After 2000, the number of attempted crossings declined but despite the lower number of deaths, the death rate continued to rise, reaching an all-time high of 833 per 100,000 attempts after 2008 (see Massey 2018).

Despite the exponential increase in the border enforcement effort after 1986 and the associated increases in the costs and risks of unauthorized border crossing, the likelihood of apprehension during an attempted clandestine crossing was largely unaffected. As shown in Fig. 9 (computed from MMP data), the probability of apprehension during any given attempt rose slightly from 1965 to 1975 (going from 0.322 to 0.405 ) before falling to a low of 0.211 in 1989. Thereafter, the probability increased to around 0.33 in 2008 before dropping to an all-time low of 0.042 in 2013 and ending up at 0.167 in 2017.

A causal analysis by Massey et al. (2016) using instrumental variables showed that the border enforcement effort had no effect on the likelihood of apprehension. However, the same causal analysis showed that border enforcement did have a strong effect in diverting the flow of undocumented migrants away from traditional crossing points, raising the costs of border crossing, and increasing the number of deaths. This set of effects radically changed the context of decision making for prospective undocumented migrants.

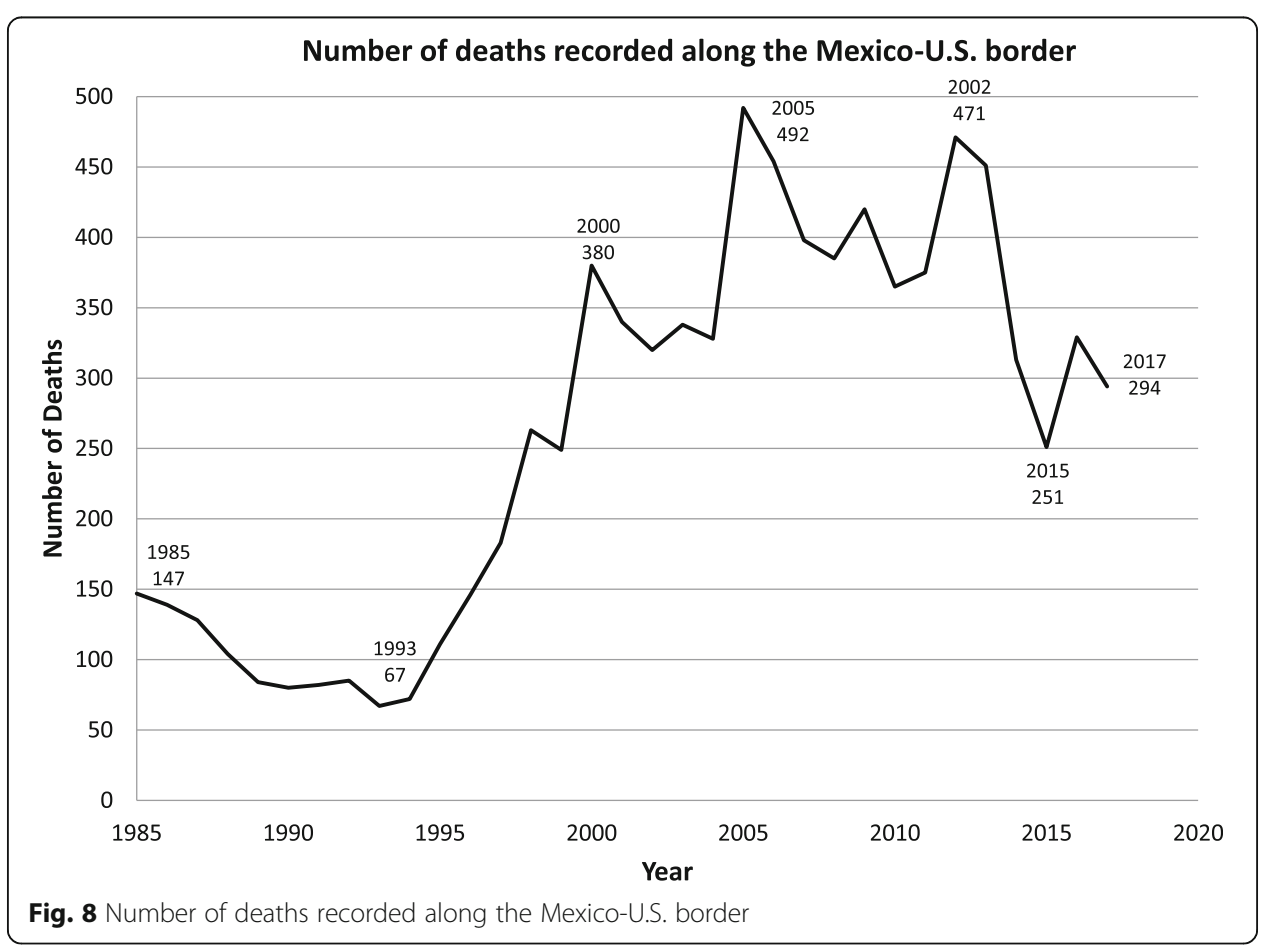




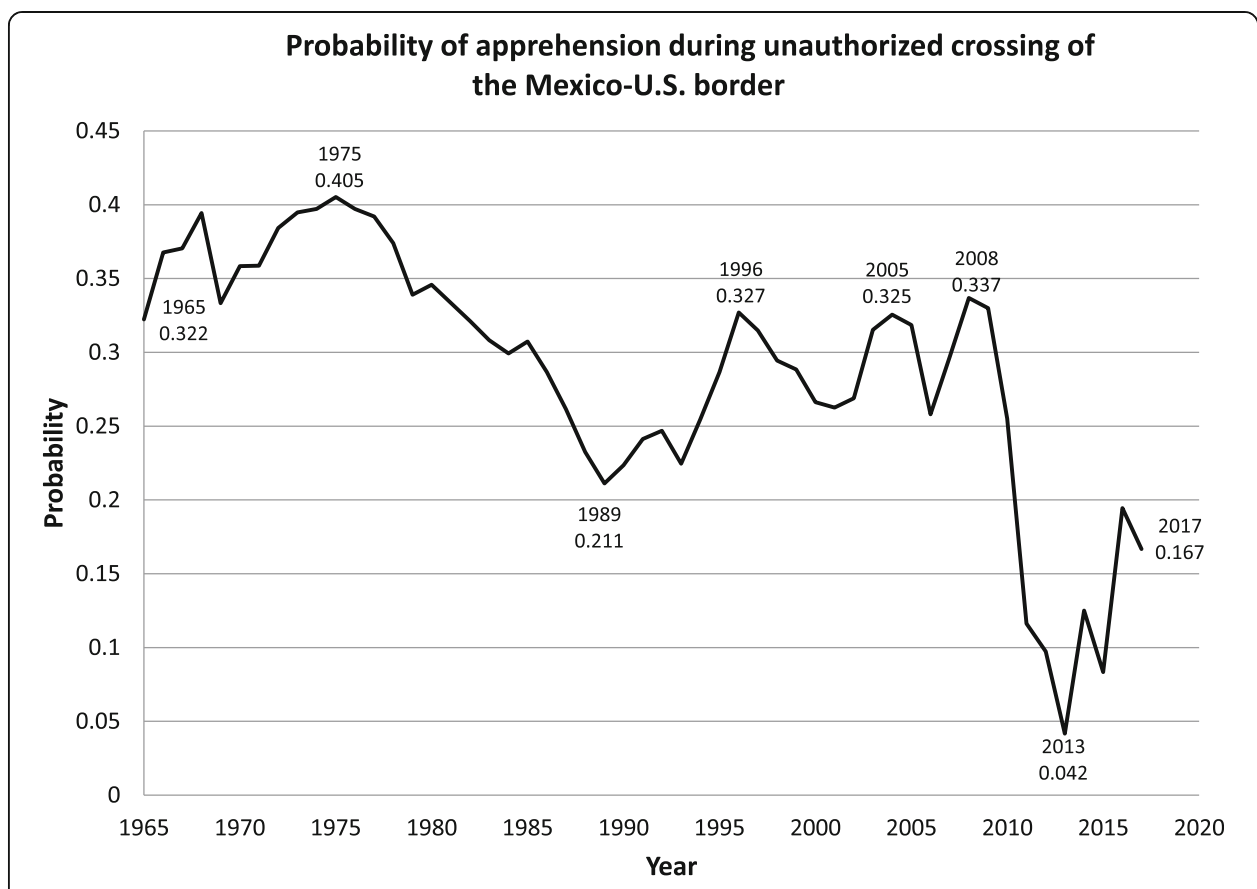

Fig. 9 Probability of apprehension during unauthorized crossing of the Mexico-U.S. border

Before 1986 undocumented migrants knew they could travel to the border and cross it surreptitiously at relatively low cost and little risk to life and limb before moving on to find fairly certain employment at a comparatively high wages in the United States. Under these circumstances, the default strategy of migration was circulatory, with most migrants moving back and forth across the border sporadically over the life cycle with relatively few settling long-term north of the border (see Massey et al. 1987).

After 1986, however, migrants came to understand that unauthorized crossings needed to occur in remote desert terrain or wild riverine valleys, making it very costly and quite risky; but they also knew that once across, they could proceed to job with high U.S. wages, just as they always had. Under these circumstances, the logical solution was to minimize border crossing, not by giving up unauthorized employment and high wages in the United States but by not returning to face the costs and risks of crossing on another trip. The causal analysis of Massey et al. (2016) showed that rising enforcement steadily reduced the likelihood of return migration back to Mexico but had no effect on likelihood of departing on a first undocumented trip.

With the rate of in-migration remaining unaffected by the massive enforcement effort but out-migration steadily and sharply declining, the net rate of in-migration rose and the net volume of undocumented migration increased sharply. This effect is illustrated in Fig. 10, which used MMP data to compute the annual number of in-migrants minus out-migrants. Whereas in 1965 net undocumented in-migration was small at just 53, 000, by 1978 it had risen to around 375,000. Although the net rate of in-migration fell during the Mexican oil boom from 1978 to 1982, it then rose to back up 508,000 in 1989 before dropping back to 369,000 in 1993 as a result of the expansion sparked by neoliberal economic restructuring under President Carlos Salinas. With the dramatic acceleration of border enforcement and the accompanying the reduction of return migration after 1993, net in-migration surged to peak at 789,000 in 1999. Thereafter net 


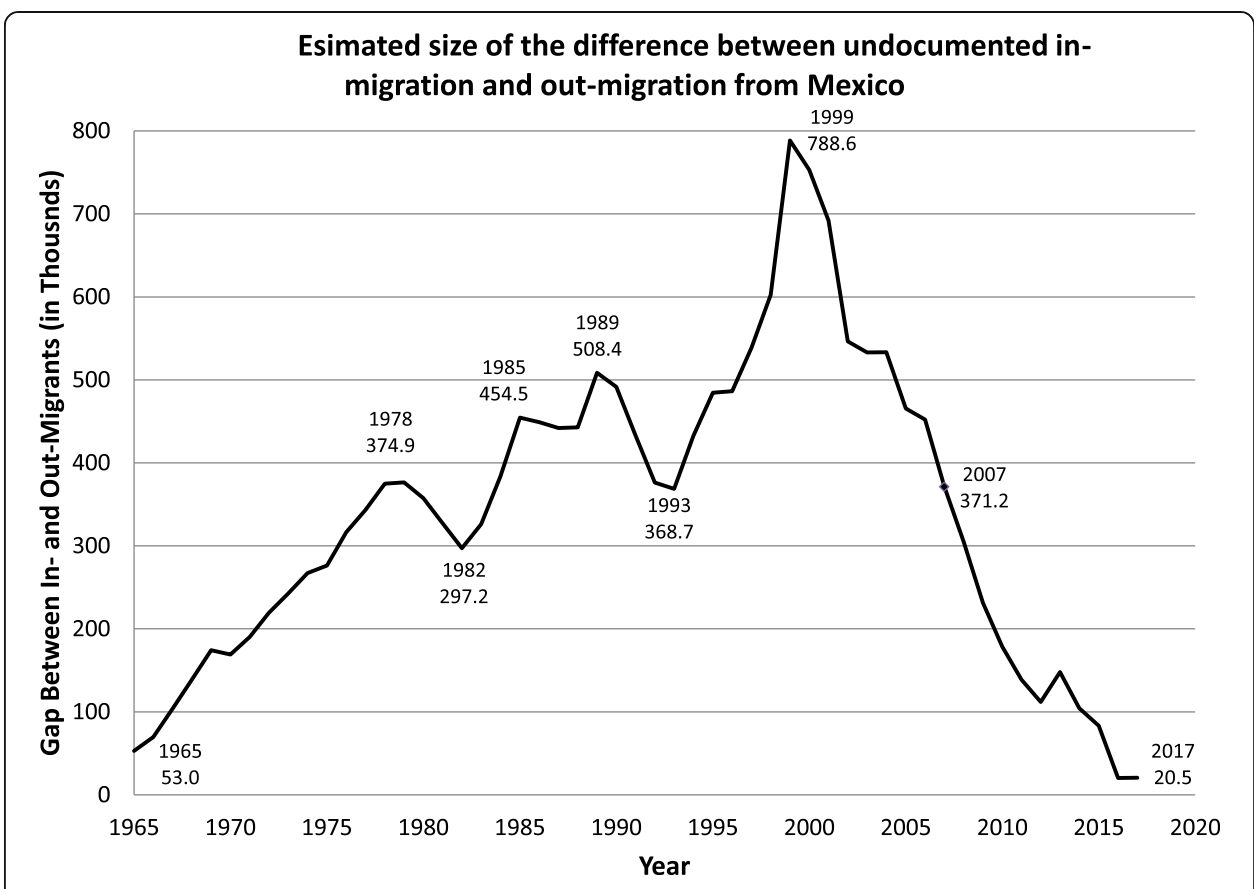

Fig. 10 Estimated size of the difference between undocumented inmigration and out-migration from Mexico

undocumented in-migration from Mexico steadily fell as rates of in-migration dropped toward zero, not because of border enforcement, but because of Mexico's demographic transition from high to low fertility rates, which increased average age in the nation out of the migration-prone age range from 18 to 29 (Massey et al. 2016).

The price of America's $20^{\text {th }}$ century immigration policy mismatch is indicated by the fact that from 1985 through 2017 the U.S. spent a total of around \$65 billion (in 2018 dollars) at a cost of 8600 border deaths (likely an underestimate) only to reduce outmigration while leaving in-migration unchanged, thereby increasing the rate of undocumented population growth by $82 \%$. In 2008 , the unauthorized population that 12.2 million persons in 2007, 57\% of whom were Mexicans, 12\% Central Americans, and 9\% from elsewhere in Latin America or the Caribbean (Passel and Cohn 2018). With the onset of the Great Recession in 2008, the undocumented population dropped to around 11 million persons, with Mexicans and other Latin Americans declining in both absolute and relative terms and Central Americans continuing to expand.

\section{The 21 st century mismatch}

Whereas international migrants in the late $20^{\text {th }}$ century generally moved from poor to rich countries in order to increase employment, raise earnings, and diversify sources of income, in the $21^{\text {st }}$ century international migrants increasingly appear to be motivated not by a desire to access opportunities but by a need to escape pressing threats to wellbeing from a variety of sources: state disintegration, civil violence, criminal predation, domestic violence, civil warfare, natural disasters, political upheavals, and economic collapse. The solid line in Fig. 11 draws on data from the United Nations High Commissioner on Refugees (2019) to show the estimated number of refugees worldwide from 1990 to 2017. 


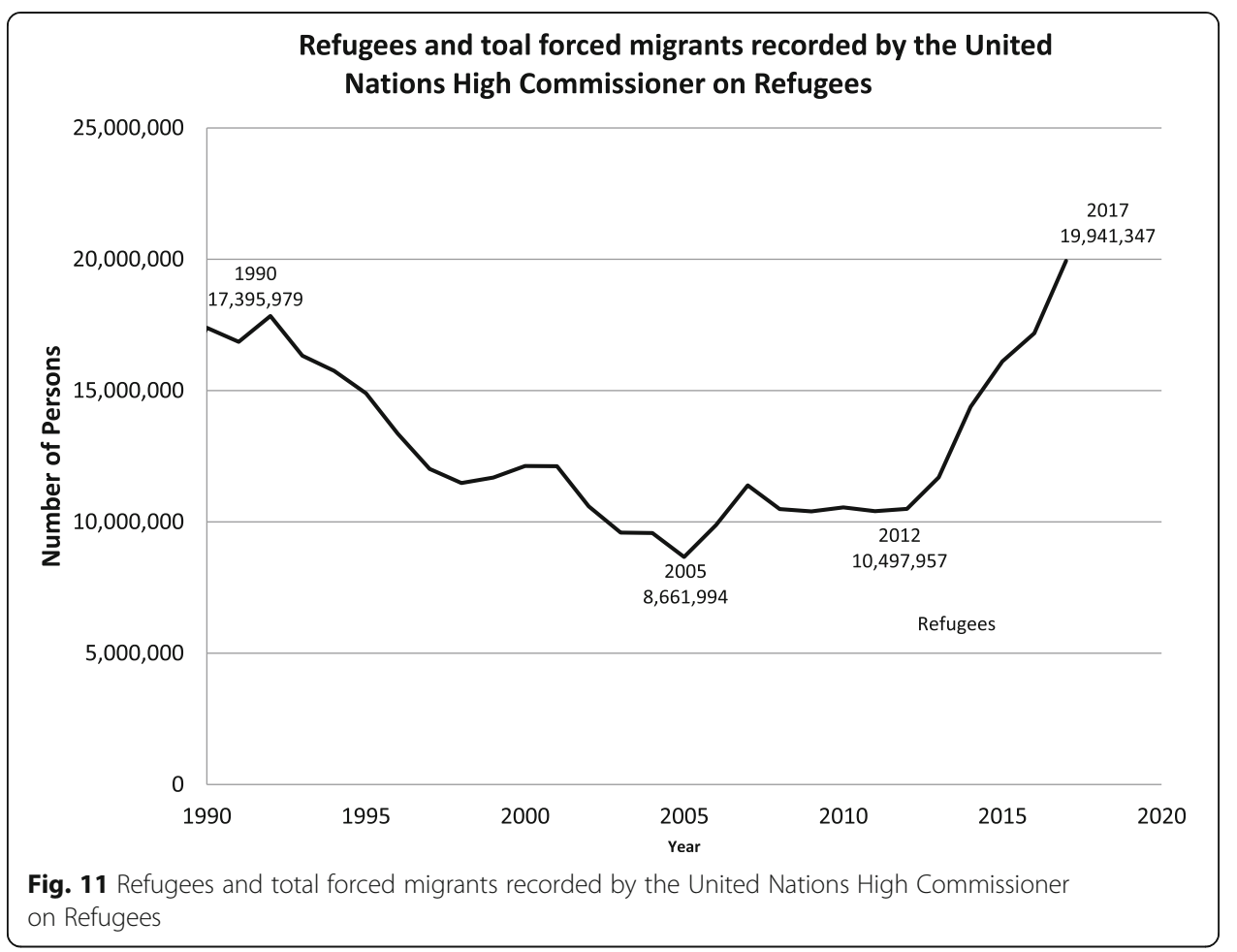

As can be seen, the worldwide population of refugees registered by the UNHCR declined steadily during the last decades of the $20^{\text {th }}$ century and into the early years of $21^{\text {st }}$ century, falling from 17.4 million in 1990 to 8.7 million in 2005. Thereafter the curve moves upward, especially after 2012 when the total refugee population already stood at 10.5 million; and by 2017 it reached 19.9 million. The latter figure includes only persons meeting the UN definition of a refugee-someone fleeing "a well-founded fear of persecution for reasons of race, religion, nationality, political opinion or membership in a particular social group." If we include persons deemed by the UNHCR to be in "refugee-like situations," such as asylum seekers, internally displaced persons, stateless persons, or others "to whom the UNHCR extends its protection and/or assistance services," the total number of forced migrants in 2017 rises to 66.5 million, up from 20.7 million in 2000.

Very clearly, then, the number of forced migrants is rising very rapidly in the first decades of the twenty-first century. Whereas the global number of international migrants rose by $46 \%$ from 2000 to 2017 , the number of refugees increased by $64 \%$ and that of all forced migrants rose by $221 \%$. El-Hinnawi (1985) was the first to theorize this new and growing flow, coining the term "environmental refugees" to describe people forced to leave their places of origin by climate change, severe weather, or the social and economic consequences of these events. Suhrke (1994) identified desertification, land degradation, deforestation, and rising sea levels as the most important forms of environmental change leading to out-migration, whereas Hugo (2008) added environmental disasters and disruptions from large scale human projects to the list of causes.

Black et al. (2011, p. 447) likewise conclude that "the effects of environmental change, including coastal flooding, reduced rainfall in drylands and water scarcity, will almost certainly alter patterns of human migration." Tacoli (2019, p. 513) concludes that 
"mobility and migration are key responses to environmental ... transformations and pressures," and therefore "the impacts of climate change are likely to affect population distribution and mobility;" and Afifi and Warner (2008) found a positive association between migration flows out of 172 countries and indicators of over-fishing, desertification, water scarcity, soil salinization, deforestation, air pollution, soil erosion, and soil pollution.

Country-specific case studies also find a clear link between environmental degradation and migration. In their study of migration in Guatemala and Sudan, Bilsborrow and DeLargy (1991) found that declining land productivity fostered out-migration from rural areas, and Hitztaler (2004) similarly found that resource-poor villages in Russia displayed higher rates of out-migration than other communities. Massey et al. (2010) showed that short-distance moves in Nepal were predicted by decreasing access to firewood, declines in agricultural productivity, and decreases in land cover.

Estimates derived by Feng et al. (2010) suggest a strong relationship between declining crop yields and out-migration from Mexico to the United States, and Munshi (2003) uncovers a significant connection between drought and Mexico-U.S. migration, a connection also observed by Nawrotzki et al. (2013). Donato and colleagues (2016) also find a strong association between the scarcity of rainfall and internal migration in Bangladesh. In their analysis of nearly five decades of data from northeastern Brazil, Barbieri et al. (2010) find that climate change had a negative effect on agricultural performance that displaced migrants to other regions of the country.

In addition to environmental change, another threat common to the contemporary world is civil violence, which may emanate from diverse sources such as crime, political terrorism, narco-terrorism, guerilla insurgencies, revolutions, and state-sponsored repression. As with environmental change, aggregate-level studies generally uncover a strong connection between violence and out-migration. Shellman and Stewart (2007) found that Haitian emigration to the United States was strongly correlated with surges in political violence, holding economic conditions constant. Morrison (1993) found similar results in Guatemala, as did Morrison and Lafaurie (1994) in Colombia.

Violence can have indirect as well as direct effects through its effects on economic growth and stability. In El Salvador, Jones (1989) found that conflict produced economic dislocations which, in turn, led to emigration, as did Morrison and May (1994) in Guatemala. A growing number of investigators have examined the connection between violence and individual and household decisions to migrate. In Colombia, for example, both Engel and Ibáñez (2007) and Ibáñez and Vélez (2008) found that the threat of violence and the presence of paramilitary and guerilla groups were strongly associated with the likelihood of out-migration; and Silva and Massey (2014) have connect rising violence in Colombia to the growth of international migration. Lundquist and Massey (2005) and Massey et al. (2014) found that migration from Central America to the United States was strongly predicted by the intensity of the U.S. Contra intervention.

Evidence is accumulating to indicate that environmental change and violence do not operate independently in generating streams of migrants around the world. Hsiang et al. (2011) show that surges in civil violence are closely tied to variations in the El Niño Southern Oscillation (ENSO). Indeed, the probability of a civil conflict roughly doubles during El Niño versus La Niña years, Hsiang et al. estimate that the ENSO may 
have been behind 21\% of all civil conflicts between 1950 and 2005. Abel et al. (2019) likewise find that climate change was significant in predicting the worldwide frequency of asylum applications through its effects on drought severity and armed conflict during, particularly in Western Asia and Africa during the period 2010-2012.

The U.S. policy mismatch 2007-2017

In sum, a growing body of research links international migration to environmental change and civil violence, and very likely to a dynamic interplay between the two. The shift of international migration away from voluntary migrants seeking jobs to forced migrants seeking refuge is clearly playing out along the southern border of the United States. What had been a very large inflow of Mexicans crossing the border in search of employment has been replaced by a smaller but significant inflow of Central Americans seeking protection. Figure 12 illustrates the shift in apprehensions away from Mexicans and toward Central Americans. Whereas the number of Mexicans apprehended at border fell from 1.6 million in 2000 to just 152,000 in 2018, the number of nonMexicans apprehended rose from 29,000 to 244,000 , with a marked acceleration between 2010 and 2014.

Data on the national origins of non-Mexican apprehensions only becomes available in 2007, but as shown in Fig. 13 as of 2011 86\% of all those apprehended were still Mexican. After that date the share steadily declines (except for a brief bump upward in 2015 ) and by 2018 the share of Mexicans had reached an all-time low of $28 \%$. In contrast, after 2011 the share of Guatemalans apprehended moved steadily upward to reach $29 \%$ in 2018, which Honduras coming in at 19\% and El Salvador at around 8\% (though down from 18\% in 2016). Together migrants from these three Central American nations comprised 56\% of all apprehensions, double the share from Mexico.

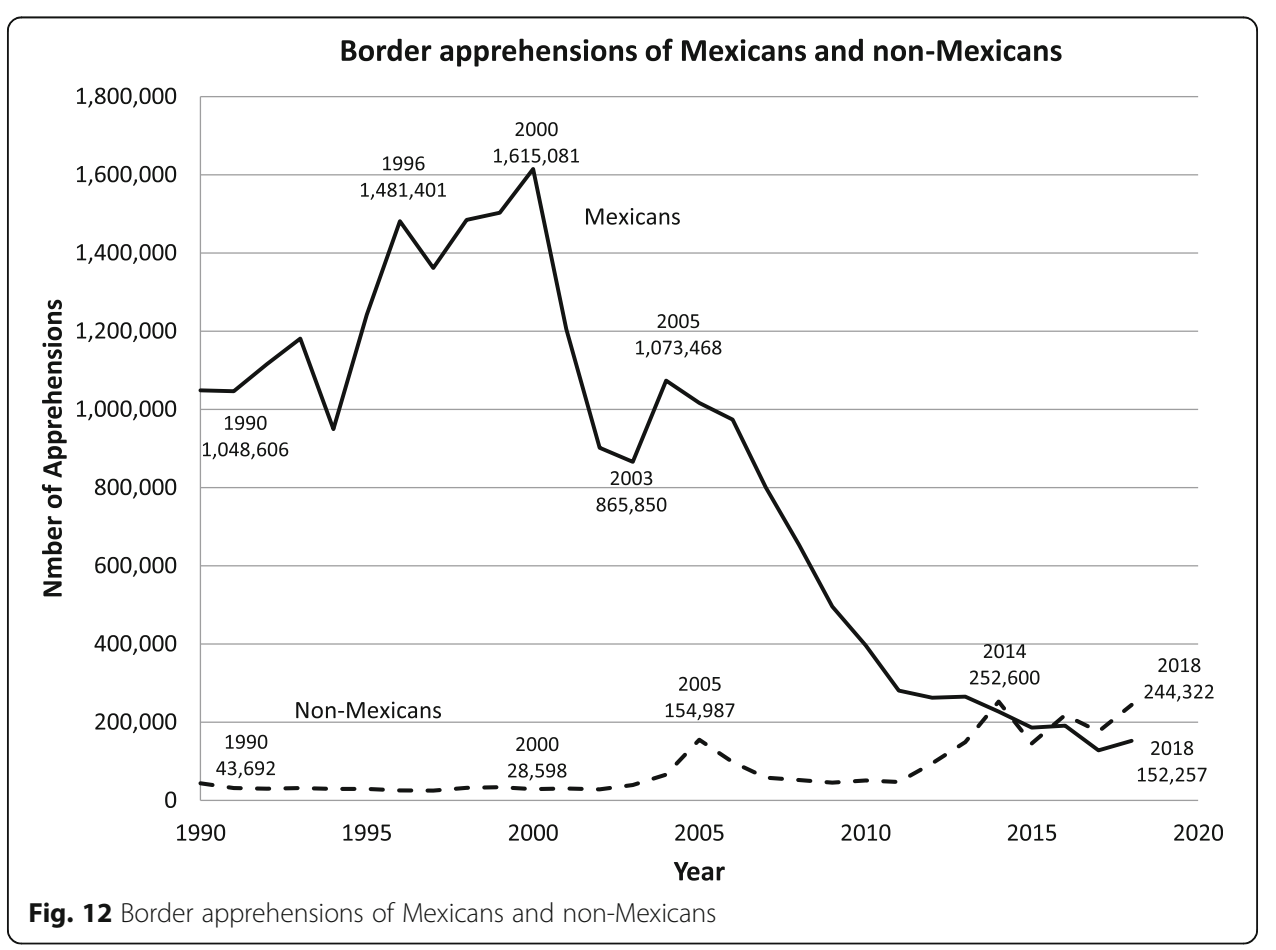




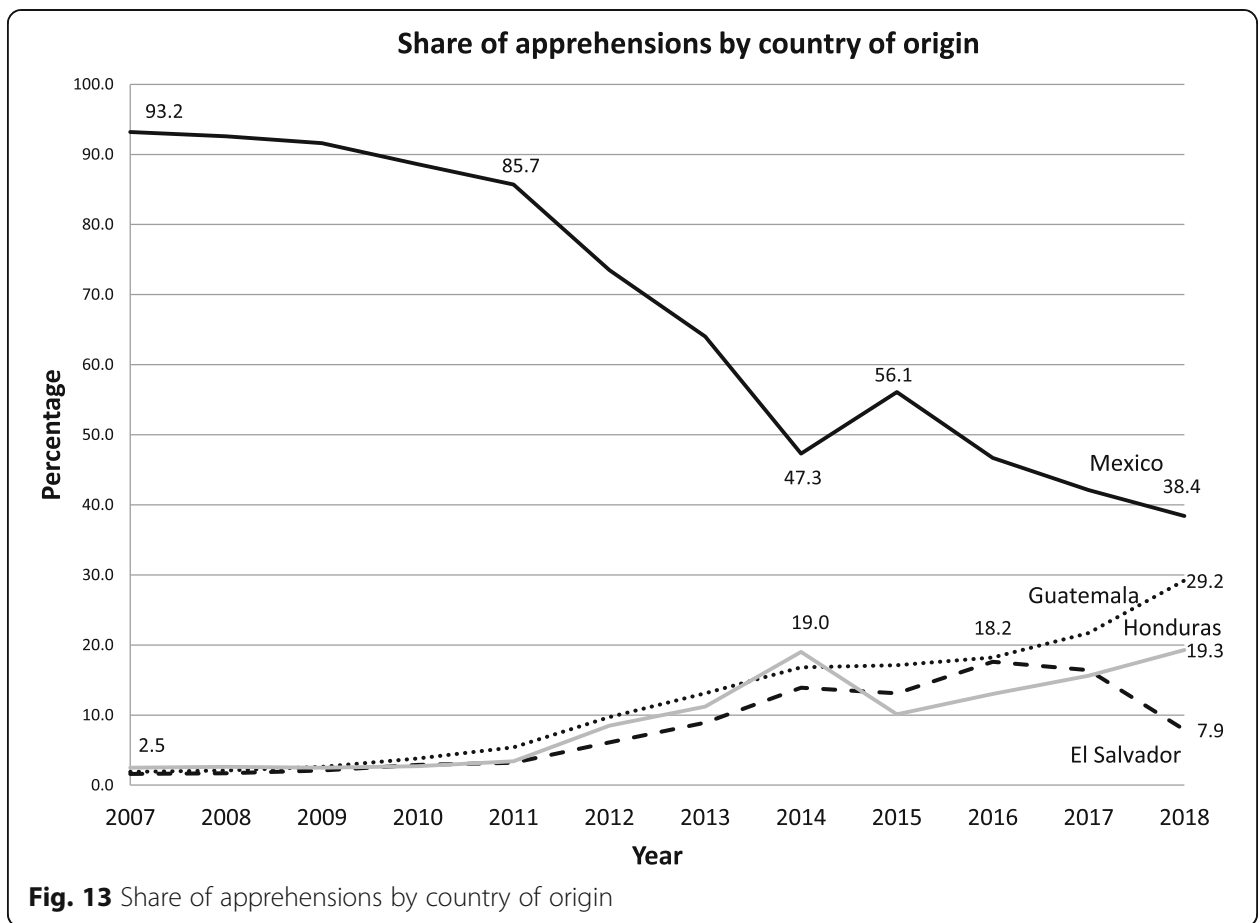

Whereas labor migration is highly selective on the basis of age and sex to yield inflows of working age males, forced migration is much less selective on these attributes and is more likely to generate inflows of women, children, and families, and this is precisely what we observe in recent border apprehensions. As shown in Fig. 14, the shift in origins away from Mexico (and labor migrants) was accompanied by a marked change in the demographic composition of those arriving at the border. As recently as 2013

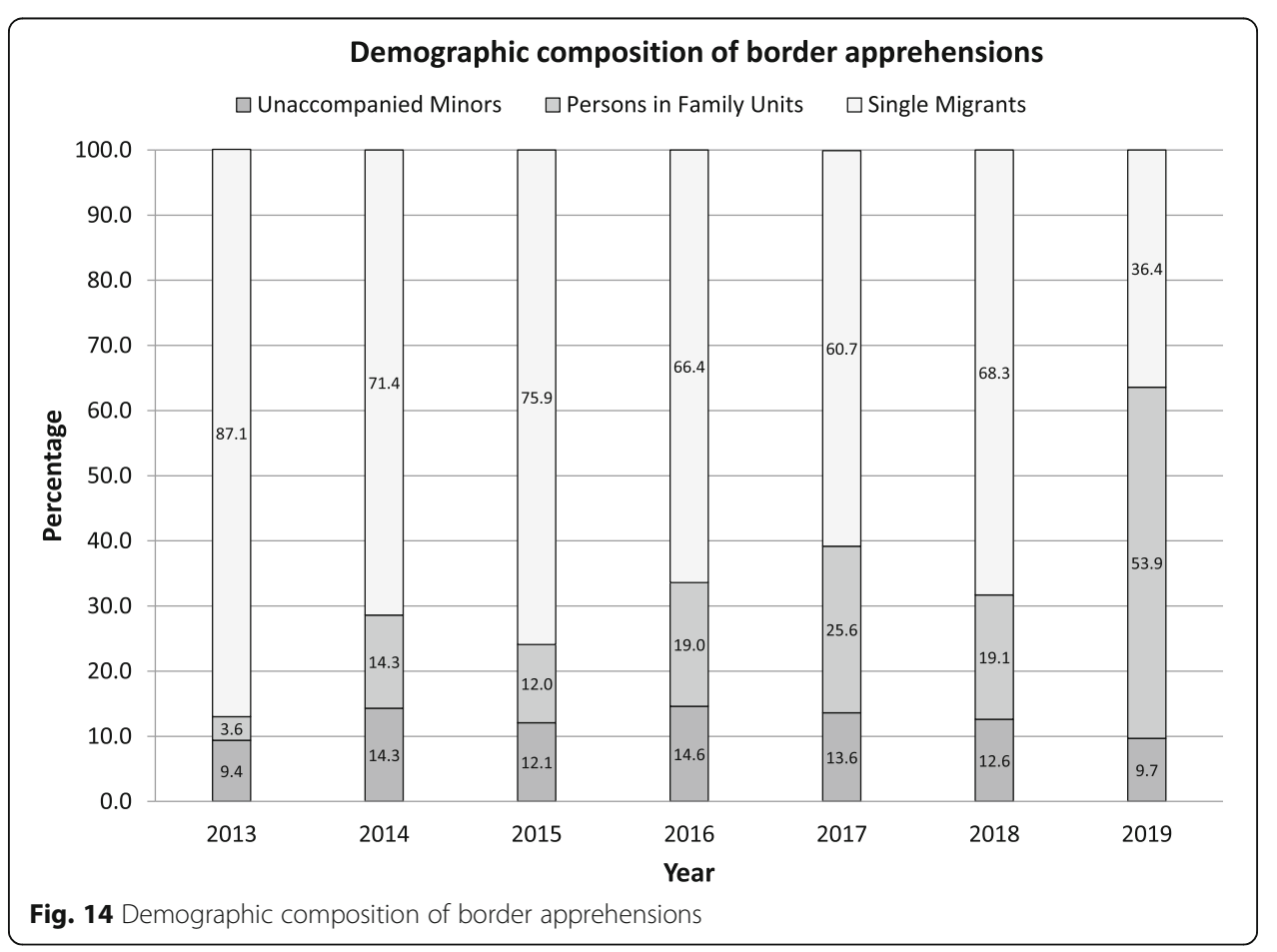


87\% of those apprehended at the Mexico-U.S. border were single migrants traveling alone (overwhelmingly men), whereas in 2017 the share of single migrants had fallen to $61 \%$ and during the first quarter of 2019 it reached just 36\%. Since 2014 the share of unaccompanied minors has varied between 10 and 15\% with no particular trend. The shift away from single migrants is primarily attributable to the rise of migrants traveling in family units, which include women and children as well as men. This category grew from under $4 \%$ of apprehensions in 2013 to 54\% during the first quarter of 2019.

The rapidity of the shift is indicated in Fig. 15, which plots monthly apprehensions from October of 2017 through April of 2019. While the monthly number of unaccompanied minors rose slowly from around 3200 to nearly 9000 over the 19 months, the number of persons apprehended in family groups suddenly shot upward in July of 2018 and then again in January of 2019. From a mere 4800 persons in October of 2017 the number apprehended in the company of family members stood at 58,500 in April of 2019, compared to around 31,600 single migrants traveling alone, the typical demographic for unauthorized migrants. In addition, as Fig. 16 shows those arriving at the border as unaccompanied minors or in family units are not Mexicans but Central Americans. Among those apprehended in family units during 2016-2018, only 3\% were Mexicans and among unaccompanied minors the figure was just $21 \%$. Only among single migrants did Mexicans constitute a sizeable plurality (43\%), compared to $16 \%$ for Hondurans 23\% for Guatemalans, and 14\% for El Salvador (yielding a total of 53\% for the Central Americans even among single migrants).

Although Central Americans may now dominate the inflow of unauthorized migrants across the border, Mexicans still predominate among undocumented migrants living in the United States, comprising a little more than half the total (Passel and Cohn 2018). These people generally entered and settled in earlier years when the inflow was still

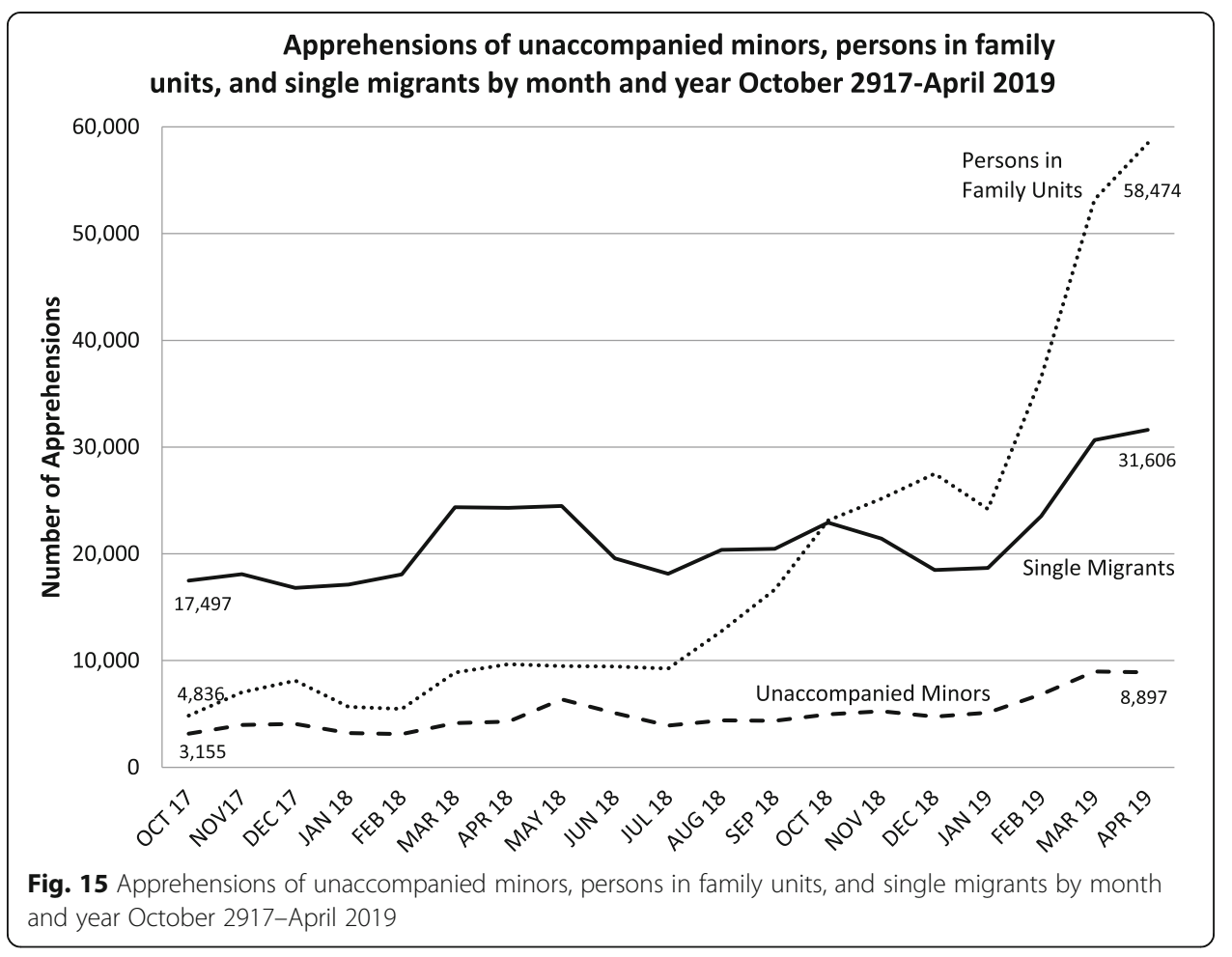




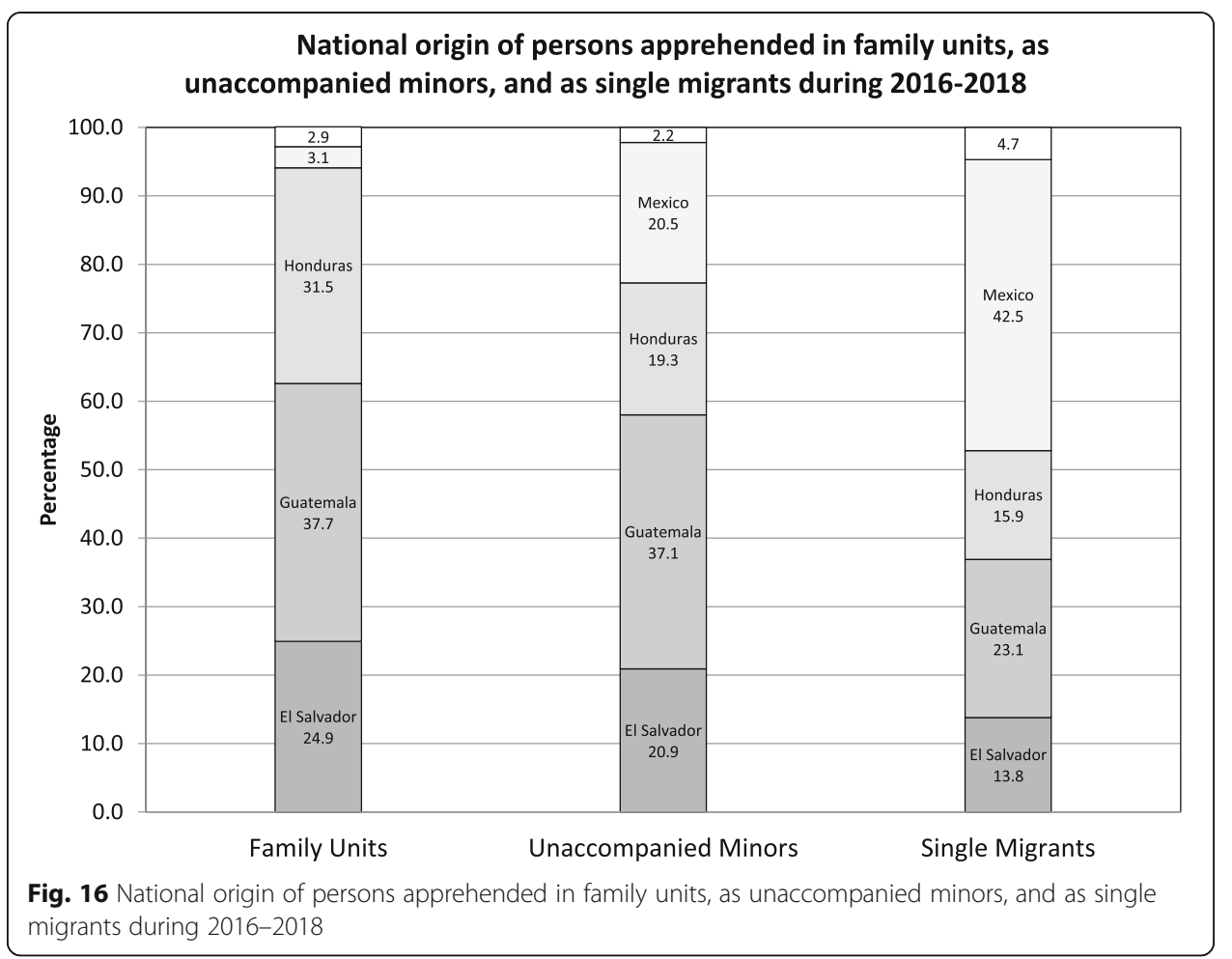

dominated by Mexicans. As of 2016, around two thirds of all undocumented U.S. residents had been in the country for more than 10 years (Passel and Cohn 2018) and for this reason Mexicans continue to dominate those detained and deported from locations in the U.S. interior. As shown in Fig. 17, the number of deportations rose very rapidly after 1990, reflecting a bipartisan policy consensus spanning the Clinton, Bush, Obama administrations.

From just 30,000 deportees in 1990 the number accelerated rapidly in the mid1990s and again after 2001 to peak at 4340002013 before falling off to 295,000 in 2017, a figure that is nonetheless very high by historical standards. Whereas the share of Mexcans among those deported rose from 49 to 82\% from 1990 to 1999, thereafter the percentage began to fall and in 2017 stood at just 65\%. As Fig. 18 indicates, the declining percentage of Mexicans among deportees corresponds with a clear increase in the share of Central Americans. From shares below $4 \%$ in 1996, the relative number of Guatemalans among deportees peaked at $13 \%$ in 2014, with same-year figures of $7 \%$ and $10 \%$ for El Salvador and Honduras respectively, together comprising $30 \%$ of all deportations (though this share fell to just $25 \%$ in 2017).

As Central Americans have increased as a share of border apprehensions and deportations, the immigration detention system has come under great strain. As shown in Fig. 19, the system is now filled to record levels with an average daily population of 40,520 in 2017 up from 28,449 just 2 years earlier. With bed space already filled, Central American families and children are increasingly being held in makeshift enclosures under bridges, in tents, in vacant buildings, and at times in the open, with children separated from their parents and record keeping on their whereabouts in disarray (Gumbel 2018). 


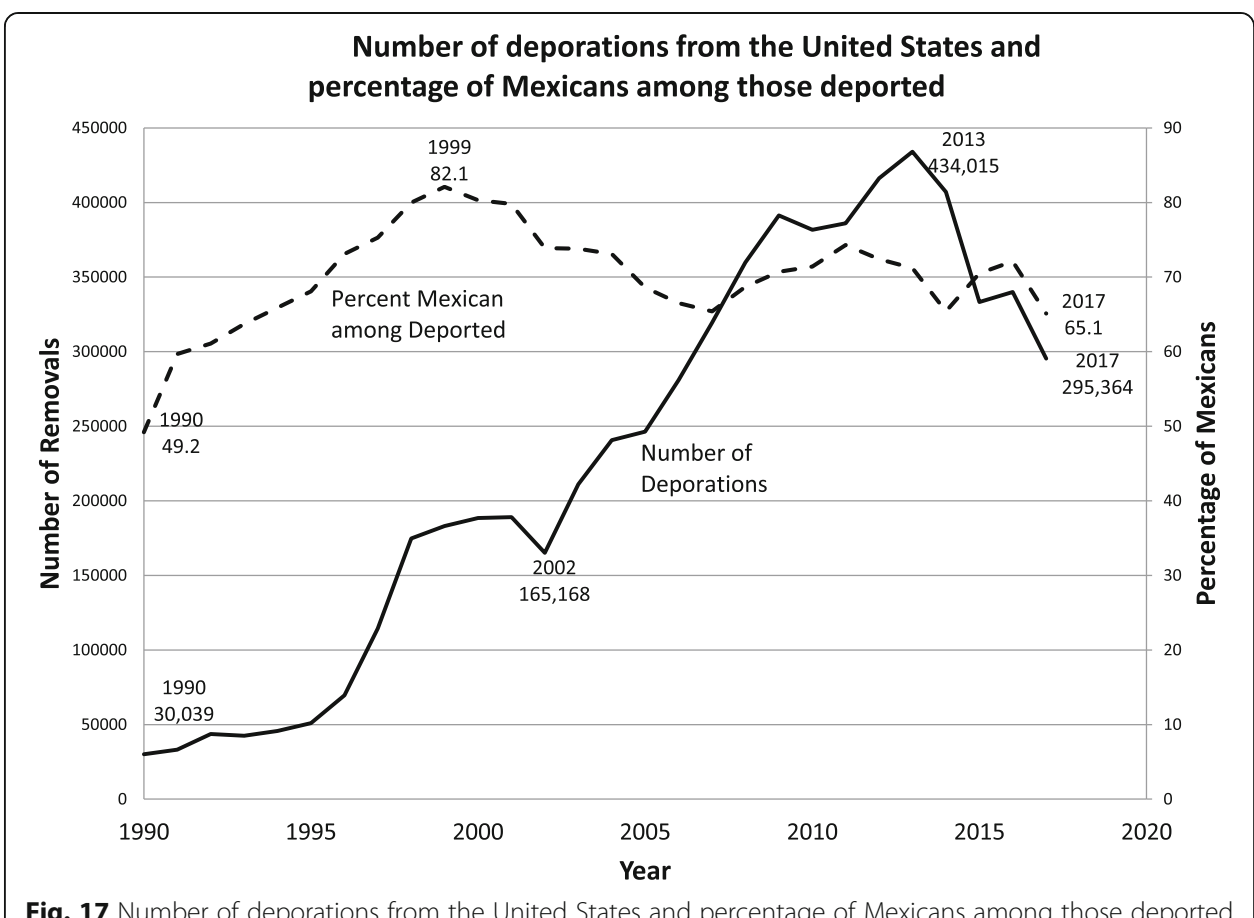

The fundamental problem is that the immigrant detention system was built to handle single male workers held for short periods prior to a speedy removal process. It was not designed to accommodate families and children resisting removal and instead waiting in long queues for their asylum claims to be processed (the backlog is currently in excess of 700,000 cases). Once again, therefore, we observe a stark policy mismatch being perpetuated by U.S. immigration authorities, who persist in treating what is

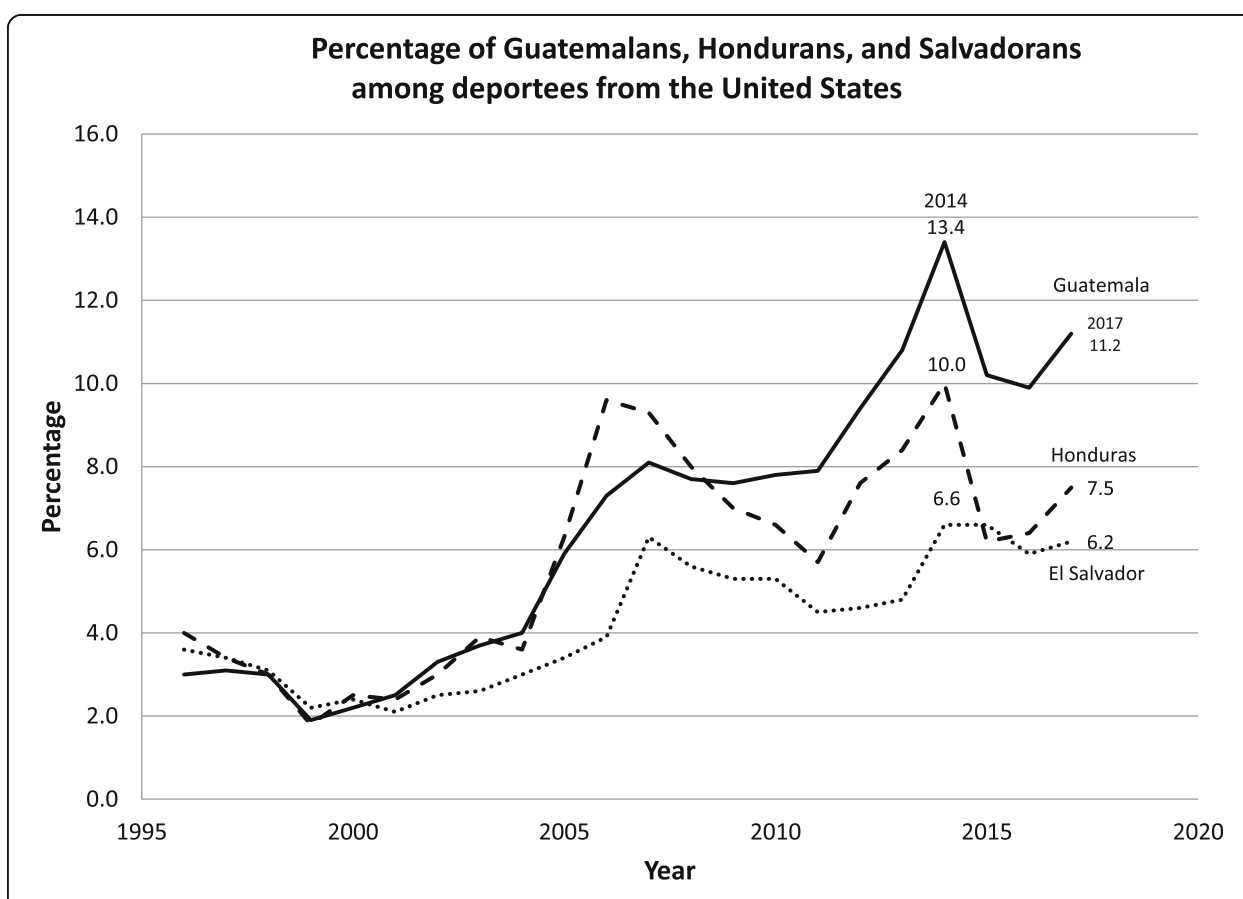

Fig. 18 Percentage of Guatemalans, Hondurans, and Salvadorans among deportees from the United States 


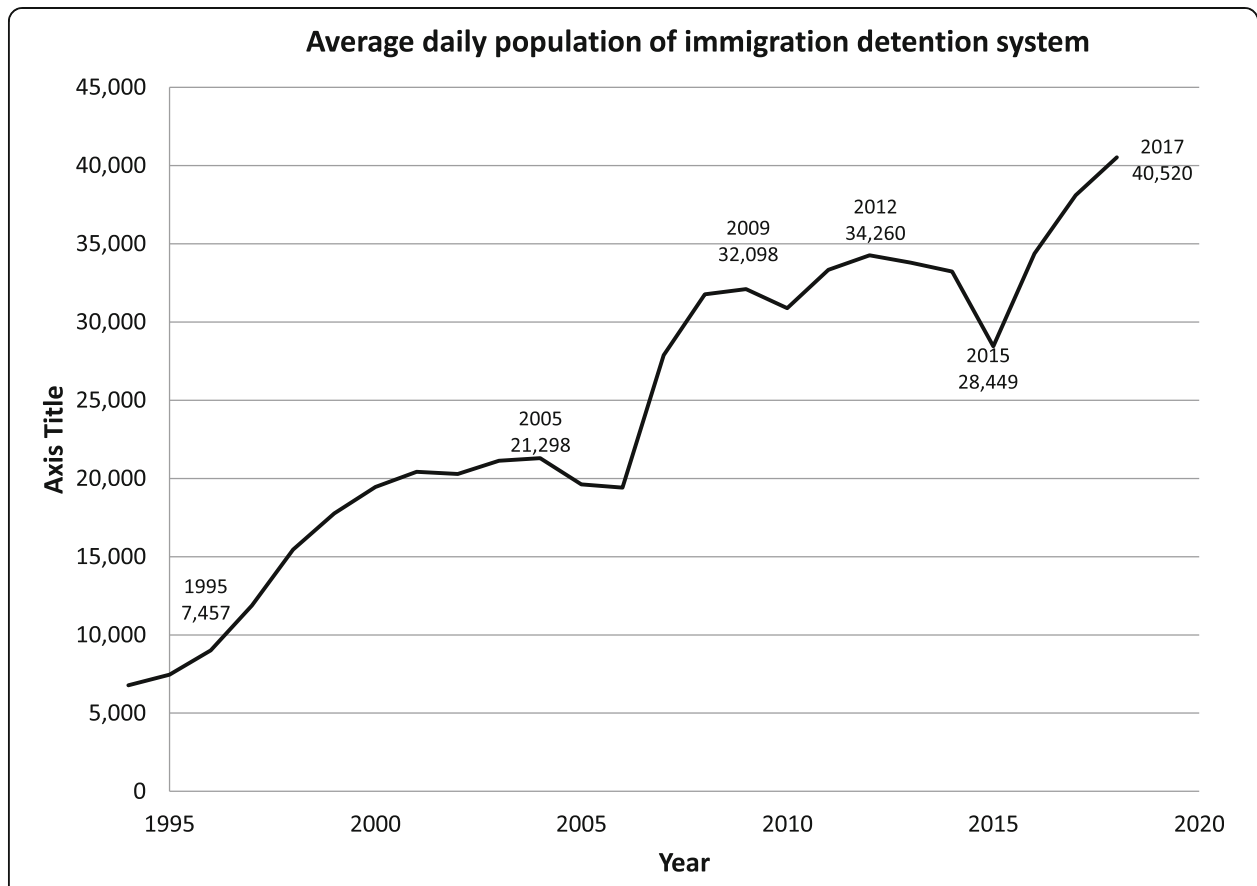

Fig. 19 Average daily population of immigration detention system

essentially a humanitarian problem as an enforcement issue requiring the application of ever more repressive actions along the border. In pursuing this policy, the United States ignores its moral responsibility for the horrendous conditions that now prevail in Central America.

Indeed, outflows can be directly traced to the U.S. military and political intervention to displace Nicaragua's left-wing Sandinista regime which had come to power in 1979 (Lundquist and Massey 2005). During the 1980s, the U.S. government provided aid to right-wing regimes in El Salvador, Guatemala, and Honduras, to train, fund, and support military units and paramilitary death squads in to suppress popular opposition in these countries, while also funding, training, and arming an army of "Contras" to fight the Sandinistas in Nicaragua itself.

In the wake of this intervention lethal violence surged, claiming hundreds of thousands of lives and destroying the region's economy. Over the course of the intervention, GDP per capita in the four frontline nations (El Salvador, Guatemala, Honduras, and Nicaragua) declined in real terms, falling from \$2619 in 1978 to \$1917 in 1989 and did not recover to its pre-intervention level until 2011 (Massey 2018). Although we do not have good data on lethal violence going back to the 1980s, as of 1995 the homicide rate in the frontline nations stood at 53.9 per hundred thousand compared with just 11.9 in the neighboring nations of Belize, Costa Rica, and Panama (Massey 2018).

Unsurprisingly people fled these conditions, with thousands heading northward to seek refuge in the United States. Prior to 1980 very few migrants departed for the United States. As shown in Fig. 20, in 1979 only around 10,500 legal immigrants entered the United States from the frontline nations. Thereafter the outflow increased, reaching 25,000 in 1988 and spiking to 136,000 in 1990 before dropping back to 28,000 in 1995. Figure 21 draws on estimates from Massey et al. (2014) to show the probability of undertaking a first undocumented trip from four Central American nations, yielding 


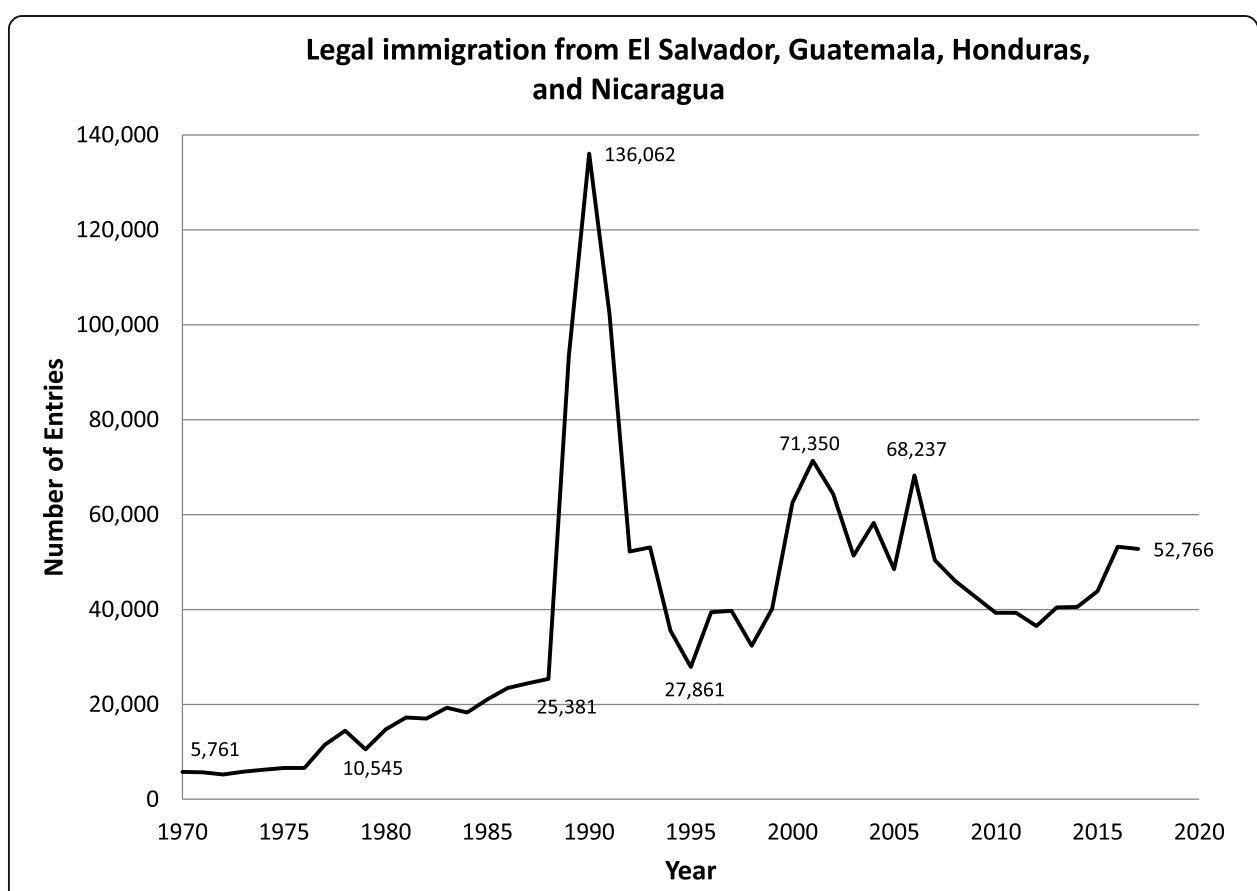

Fig. 20 Legal immigration from El Salvador, Guatemala, Honduras, and Nicaragua

a cover that displays much the same temporal pattern. The likelihood of undocumented departure averaged just 0.001 through 1979 but thereafter rose rapidly to peak at 0.007 in 1989 before dropping back to 0.003 in 1995.

As the U.S. intervention wound down in the 1990s, however, neither documented nor undocumented migration returned to the status quo ante. As already noted, the regional economy never really recovered (in 2017 GDP per capita in the frontline nations

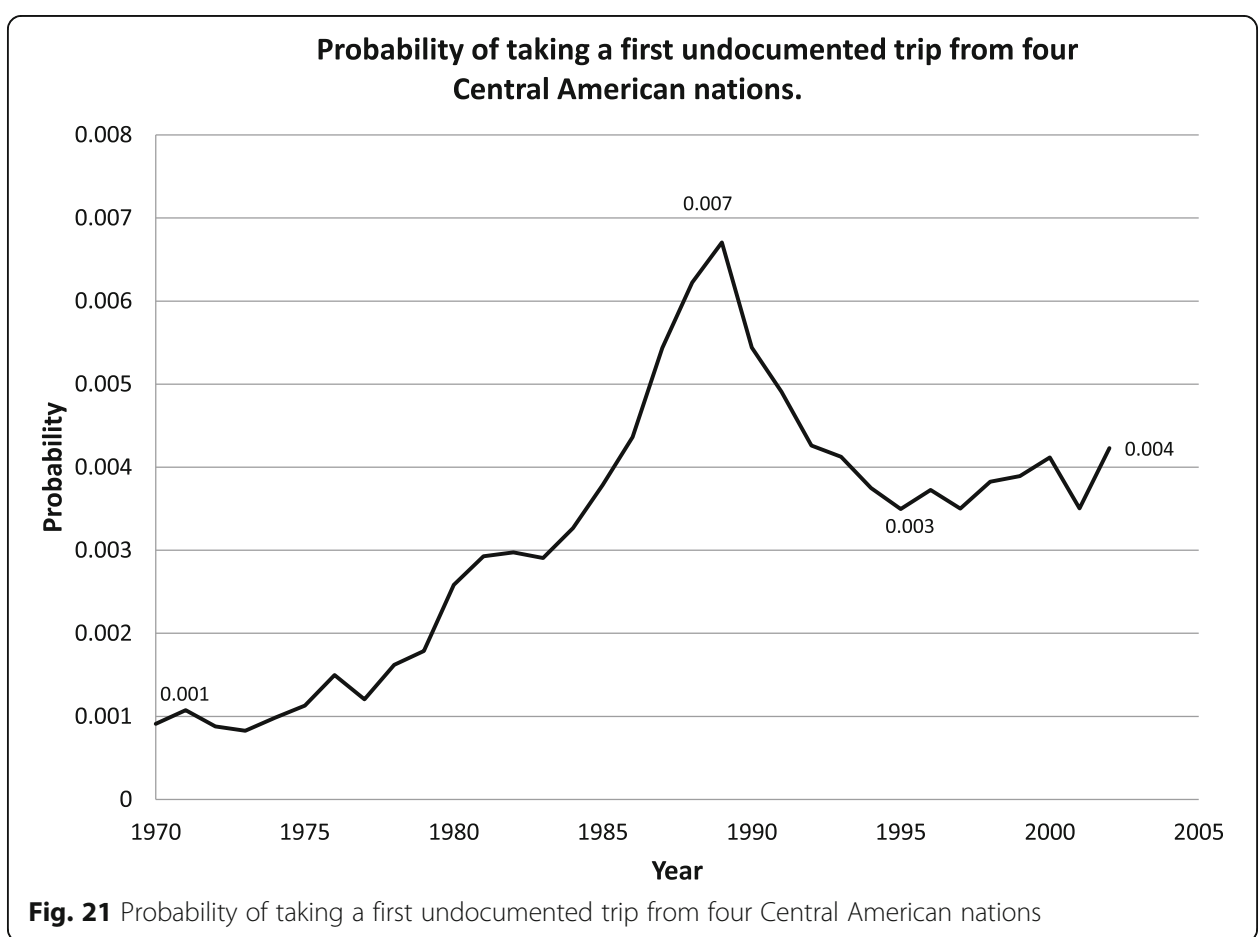


was only $14 \%$ above its 1978 level in real terms). At the same time, violence had become endemic within the region, in no small way because the large-scale deportation of Central American gang members from Los Angeles during the 1990s (Wolf 2012). By 2015 some 3.1 million Salvadorans, Guatemalans, Hondurans, and Nicaragua entered the United States (Passel and Cohn 2017), providing relatives still in the region with connections either to enter legally using the family reunification provisions of U.S. immigration law or to head northward without authorization to join undocumented family members living north of the border (Massey et al. 2014). Although many of those now arriving to claim asylum have family members in the United States, more than half of all Central Americans now living in the United States are present without authorization (Passel and Cohn 2017).

\section{Future immigration policy: the U.S. and Europe}

The late $20^{\text {th }}$ century and the early $21^{\text {st }}$ century are proving to be very different epochs. Whereas the former corresponded to an era of triumphant globalism under a neoliberal ideology that celebrated the fluid movement of goods, capital, information, services, and people across international borders, the latter is characterized by a populist reaction against globalization and a concomitant surge in white nationalism supported by authoritarian ideologies that openly challenge the global openness favored by neoliberal elites. Whereas immigrants in that earlier era were generally motivated by a desire to access economic opportunities and improve their lives, today they are increasingly motivated by a desire to escape threats and save their lives.

Migrants moving to offer their labor and human capital on global labor markets tend to be of working age, predominantly male, and interested in circular movement, whereas those moving to seek refuge and shelter disproportionately comprise women and children who are not interested in returning home anytime soon. Despite these differences, in both eras immigrants have tended to be framed as threats: alleged to be driving wages down and unemployment up in the late $20^{\text {th }}$ century, and portending racial replacement and cultural extinction for people of European origin in the $21^{\text {st }}$ century. In each case, the repressive immigration policy regimes associated with these fearbased narratives failed to recognize the underlying motivations for international movement and yielded policy mismatches that led to dysfunctional outcomes.

The massive settlement of Mexican migrants during the 1990s cannot be undone, and the United States is projected to become 22\% Latino by 2035, up from $18 \%$ today and just 4.7\% in 1970 (U.S. Census Bureau 2017). However, roughly half of all Latino immigrants are unauthorized and most now occupy households containing U.S.-born citizen children. More than 5.1 million children under the age of 18 live with at least one unauthorized parent, 4.1 million of whom are U.S. citizens; and these children are severely disadvantaged compared to the children of legal immigrants or U.S. citizens (Capps et al. 2016). The longer their parents remain undocumented and subject to a relentless regime of detention and deportation, the worse it will be for U.S. society as the second generation comes of age.

The obvious solution to this problem is to legalize the country's 11 million undocumented migrants, the vast majority of whom have no criminal record and constitute no threat to the public welfare. This total includes more than a million people brought to the United States as children who have grown up as Americans and know no other 
country. Not only would legalization benefit those currently out of status and the nation as a whole, it would also create potential sponsors for the asylum seekers currently arriving at the nation's southern border. Unfortunately, although legalization is supported by a majority of U.S. voters (National Immigration Forum 2017), it is unlikely to occur in an administration dominated by white nationalists who peddle fear, xenophobia, and racism.

Dealing effectively with refugees and asylum seekers from Central America is certainly within the nation's capacity to manage. During the late 1970s and early 1980s, the United States successfully accepted, processed, and integrated a much larger inflow of "boat people" from Southeast Asia. Just as in Central America, the United States had a moral obligation to accept those escaping the chaotic consequences of the U.S. intervention in Vietnam, and as shown in Fig. 22 at that time the obligation was recognized and translated into policy. Between 1977 and 1998 the United States admitted some 1.3 million Southeast Asians as immigrants to the United States.

As in Central America, there was no U.S.-bound migration prior to the American intervention. Through 1977 no more than 5000 migrants from the region had ever been admitted into the United States in a single year. Then following the collapse of the South Vietnamese regime the number surged to 97,000 in 1978. These initial departures were followed by the mass exodus of others on rickety boats, and after their arrival and processing in regional camps and transport to the United States they too were admitted as permanent U.S. residents, with notable peaks in 1982 and 1992. As in Central America, however, immigration to the United States did not return to the status quo ante of no migration before the U.S. intervention.

There is no humane rationale for treating Central Americans any differently than Southeast Asians, and indeed the potential number of refugees is much smaller. Whatever the morality of the current U.S. position, the situation it faces during the new

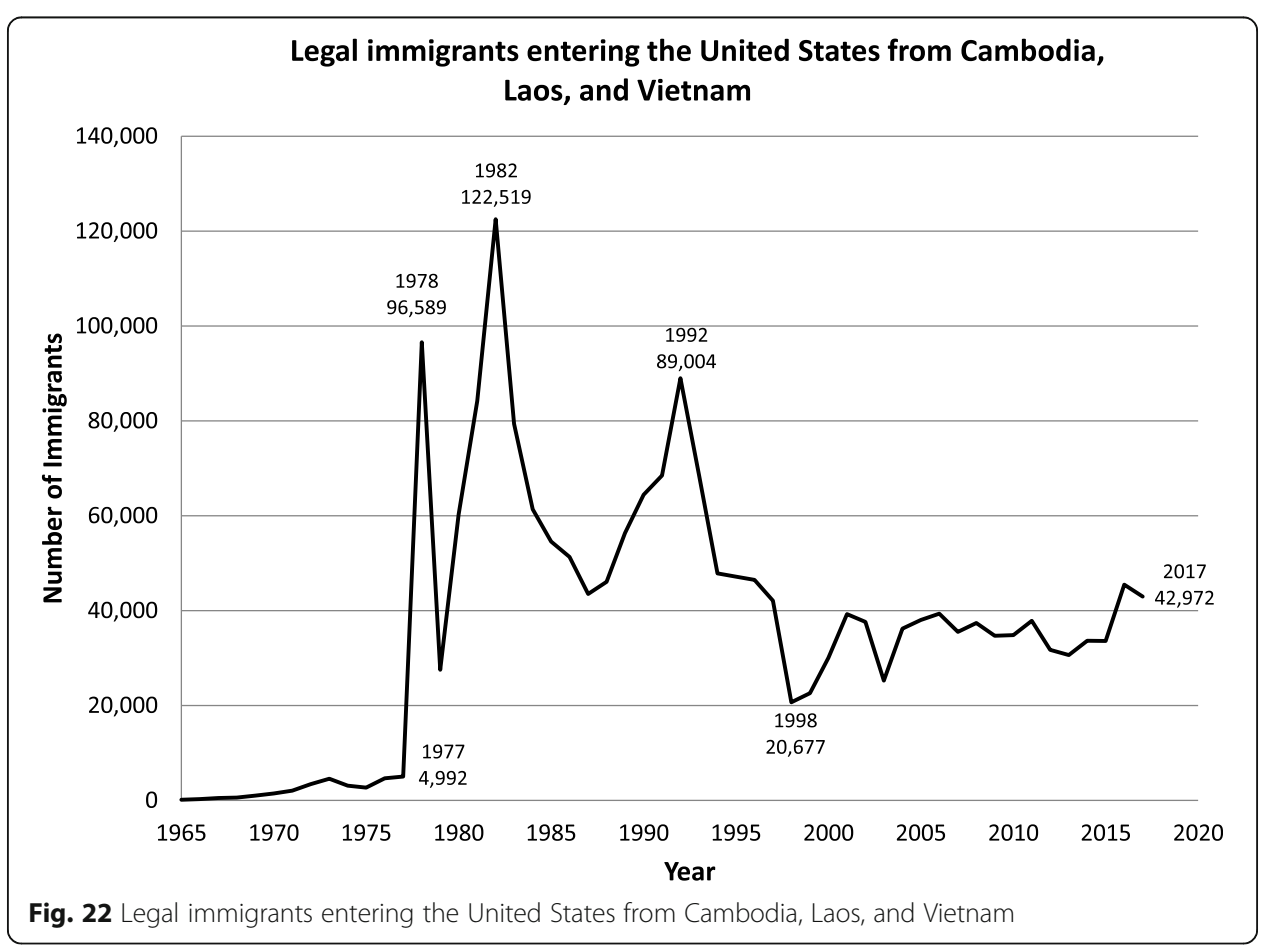


epoch climate change, rising violence, and forced migration is far less daunting than that faced by Europe. The fertility rate in Latin America and the Caribbean is below replacement level fertility, with aging populations, slowing rates of population growth. In addition, nations south of the United States are mostly middle income economies, with a regional per capita income $\$ 14,500$ (in 2017 purchasing power parity dollars). In contrast, below Europe Africa has an average fertility rate of 4.4 births per woman, with populations that are young and rapidly growing and a regional per capita income of just $\$ 3800$ and great vulnerabilities to climate change, extreme weather, and violence. Given these circumstances and the region's longstanding colonial ties to Europe, the mismatch between migrant needs and immigration policies is likely to be much greater in Europe than in the United States.

\section{Supplementary information}

Supplementary information accompanies this paper at https://doi.org/10.1186/s40878-020-00181-6.

\section{Additional file 1.}

Additional file 2 .

\section{Acknowledgements}

The author has no additional acknowledgements besides the foregoing recognition of the funding source.

\section{Author's contributions}

DSM prepared all the data and figures, analyzed and interpreted these materials, and himself wrote the entire article. The author(s) read and approved the final manuscript.

\section{Funding}

Research reported in this publication was supported by The Eunice Kennedy Shriver National Institute of Child Health \& Human Development of the National Institutes of Health under Award Numbers P2CHD047879 and R01HD35643. The content is solely the responsibility of the authors and does not necessarily represent the official views of the National Institutes of Health.

\section{Availability of data and materials}

All data generated or analyzed during this study are included in this published article and its supplementary information files.

\section{Competing interests}

The author declares that he has no competing interests.

Received: 20 September 2019 Accepted: 6 May 2020

Published online: 25 June 2020

\section{References}

Abel, G. J., Brottrager, M., Cuaresma, J. C., \& Muttarak, R. (2019). Climate, conflict and forced migration. Global Environmental Change, 54, 239-249.

Afifi, T., \& Warner, K. (2008). The impact of environmental degradation on migration flows across countries (Working paper no. 5). Bonn: United Nations University Institute for Environment and Human Security (UNU-EHS).

Barbieri, A. F., Domingues, E., Queiroz, B. L., Ricardo, M., Rigotti, J. I., Carvalho, J. A. M., \& Resende, M. F. (2010). Climate change and population migration in Brazil's northeast: scenarios for 2025-2050. Population and Environment, 31, 344-370.

Bilsborrow, R. E., \& DeLargy, P. F. (1991). Population growth, natural resource use and migration in the third world: the cases of Guatemala and Sudan. Population and Development Review, 16, S125-S147.

Black, R., Bennett, S. R. G., Thomas, S. M., \& Beddington, J. R. (2011). Migration as Adaptation. Nature, 478, 447-449.

Calavita, K. (1992). Inside the state: the Bracero Program, immigration, and the I.N.S. New York: Routledge.

Capps, R., Fix, M., \& Zong, J. (2016). A profile of immigrants with unauthorized parents. Washington, DC: Migration Policy Institute. https://www.migrationpolicy.org/research/profile-us-children-unauthorized-immigrant-parents.

Chavez, L. R. (2008). The Latino Threat: constructing immigrants, citizens, and the nation. Stanford: Stanford University Press.

Cuddy, A. J. C., Fiske, S. T., \& Glick, P. (2008). Competence and warmth as universal trait dimensions of interpersonal and intergroup perception: the stereotype content model and the BIAS map. In M. P. Zanna (Ed.), Advances in Experimental Social Psychology, 40 (pp. 61-149). New York: Academic Press.

Cuddy, A. J. C., Fiske, S. T., Kwan, V. S. Y., Glick, P., Demoulin, S., Leyens, J.-P., ... Ziegler, R. (2009). Stereotype content model across cultures: Towards universal similarities and some differences. British Journal of Social Psychology, 48, 1-33.

Daniels, R. (2004). Guarding the golden door: American immigration policy and immigrants since 1882. New York: Hill and Wang.

Donato, K. M., Carrico, A. R., Sisk, B., \& Piya, B. (2016). Different but the Same: How Legal Status Affects International Migration from Bangladesh. Annals of the American Academy of Political and Social Science, 666, 203-218. 
Dustmann, C., \& Görlach, J.-S. (2016). The economics of temporary migrations. Journal of Economic Literature, 54(1), 98-136. El-Hinnawi, E. (1985). Environmental refugees. Nairobi: United Nations Environment Programme.

Engel, S., \& Ibáñez, A. M. (2007). Displacement due to violence in Colombia: a household-level analysis. Economic Development and Cultural Change, 55(4), 335-365.

Eschbach, K., Hagan, J., \& Rodriguez, N. (2001). Causes and trends in migrant deaths along the US-Mexican border 1985-1998 (Working paper series 01-4). Houston: Center for Immigration Research, University of Houston.

Feng, S., Krueger, A. B., \& Oppenheimer, M. (2010). Linkages among climate change, crop yields and Mexico-US cross-border migration. Proceedings of the National Academy of Sciences, 107(32), 14257-14262.

Fiske, S. T., Cuddy, A. J. C., \& Glick, P. (2007). Universal dimensions of social perception: warmth and competence. Trends in Cognitive Science, $11,77-83$.

Fiske, S. T., Cuddy, A. J. C., Glick, P., \& Jun, X. (2002). A model of (often mixed) stereotype content: competence and warmth respectively follow from perceived status and competition. Journal of Personality and Social Psychology, 82, 878-902.

Fiske, S. T. (2014). Social Beings: Core Motives in Social Psychology (4th ed.). New York: Wiley.

Goldin, C. (1994). The political economy of immigration restriction in the U.S., 1890 to 1921. In C. Goldin, \& G. Libecap (Eds.), The regulated economy: a historical approach to political economy (pp. 223-257). Chicago: University of Chicago Press.

Gumbel, A. (2018, September 12). 'They were laughing at us': immigrants tell of cruelty, illness and filth in US detention. The Guardian. https://www.theguardian.com/us-news/2018/sep/12/us-immigration-detention-facilities.

Hatton, T. J., \& Williamson, J. G. (1998). The age of mass migration: causes and economic impact. Oxford: Oxford University Press.

Higham, J. (1981). Strangers in the land: patterns of American nativism, 1860-1925. Westport: Greenwood Press.

Hitztaler, S. (2004). Changing human populations in post-Soviet Kamchatka: an integrated study of shifts in fertility and net population. Population and Environment, 25(4), 335-354.

Hsiang, S. M., Meng, K. C., \& Crane, M. A. (2011). Civil conflicts are associated with the global climate. Nature, 476, 438-441.

Hugo, G. (2008). Migration, development and environment (IOM migration research series no 35). Geneva: International Organization for Migration.

Ibáñez, A. M., \& Vélez, C. E. (2008). Civil conflict and forced migration: the micro determinants and welfare losses of displacement in Colombia. World Development, 36(4), 659-676.

Jones, R. C. (1989). Causes of Salvadoran migration to the United States. The Geographical Review, 79, 193-194.

Lamont, M., \& Molnar, V. (2002). The study of boundaries in the social sciences. Annual Review of Sociology, 28, 167-195.

Lee, T. L., \& Fiske, S. T. (2006). Not an outgroup, but not yet an ingroup: immigrants in the stereotype content model. International Journal of Intercultural Relations, 30, 751-768.

Lundquist, J. H., \& Massey, D. S. (2005). Politics or economics? International migration during the Nicaraguan Contra War. Journal of Latin American Studies, 37(1), 29-53.

Martin, P. L., \& Miller, M. J. (1980). Guestworkers: lessons from Western Europe. Industrial and Labor Relations Review, 33(3), $315-330$.

Massey, D. S. (1988). International migration and economic development in comparative perspective. Population and Development Review, 14, 383-414.

Massey, D. S. (1990). Social structure, household strategies, and the cumulative causation of migration. Population Index, 56, 3-26.

Massey, D. S. (2013). From immigration restriction to immigration management. UN Chronicle, 50(3), 16-17.

Massey, D. S. (2018). Doubling Down on a Bad Bet: Immigration Policy Before and after Trump, Paper presented at a conference sponsored by the Lefrak Forum on "A 21st Century Immigration Policy for the West". East Lansing: Michigan State University, October 11-13.

Massey, D. S., Alarcon, R., Durand, J., \& Gonzalez, H. (1987). Return to Aztlan: The Social Process of International Migration from Western Mexico. Berkeley: University of California Press.

Massey, D. S., Arango, J., Hugo, G., Kouaouci, A., Pellegrino, A., \& Edward Taylor, J. (1998). Worlds in motion: international migration at the end of the millennium. Oxford: Oxford University Press.

Massey, D. S., Axinn, W. G., \& Ghimire, D. J. (2010). Environmental change and out-migration: evidence from Nepal. Population and Environment, 32(2-3), 109-136.

Massey, D. S., \& Capoferro, C. (2004). Measuring undocumented migration. International Migration Review, 38, 1075-1102.

Massey, D. S., Durand, J., \& Malone, N. J. (2002). Beyond smoke and mirrors: Mexican immigration in an age of economic integration. New York: Russell Sage Foundation.

Massey, D. S., Durand, J., \& Pren, K. A. (2014). Explaining undocumented migration to the U.S. International Migration Review, 48(4), 1028-1061.

Massey, D. S., Durand, J., \& Pren, K. A. (2016). Why border enforcement backfired. American Journal of Sociology, 121(5), 15571600.

Massey, D. S., \& Gentsch, K. (2014). Undocumented migration and the wages of Mexican immigrants in the United States. International Migration Review, 48(2), 482-499.

Massey, D. S., \& Liang, Z. (1989). The long-term consequences of a temporary worker program: the U.S. Bracero experience. Population Research and Policy Review, 8, 199-226.

Massey, D. S., \& Pren, K. A. (2012a). Unintended consequences of US immigration policy: explaining the post-1965 surge from Latin America. Population and Development Review, 38(1), 1-29.

Massey, D. S., \& Pren, K. A. (2012b). Origins of the New Latino underclass. Race and Social Problems, 4(1), 5-17.

Massey, D. S., \& Singer, A. (1995). New estimates of undocumented Mexican migration and the probability of apprehension. Demography, 32, 203-213.

Massey, D. S., \& Zenteno, R. (2000). A validation of the ethnosurvey: the case of Mexico-U.S. migration. International Migration Review, 34, 765-792.

McPherson, M., Smith-Lovin, L., \& Cook, J. M. (2001). Birds of a feather: homophily in social networks. Annual Review of Sociology, 27, 415-444.

Meyers, E. (2007). International immigration policy: a theoretical and comparative analysis. New York: Palgrave Macmillan. 
Morrison, A. R., \& Lafaurie, M. P. (1994). Elites, guerrillas and narcotraficantes: violence and internal migration in Colombia. Canadian Journal of Latin American and Caribbean Studies, 19(37-38), 123-154.

Morrison, A. R., \& May, R. A. (1994). Escape from terror: violence and migration in post-revolutionary Guatemala. Latin American Research Review, 29(2), 111-132.

Morrison, A. R. (1993). Violence or Economics: What Drives Internal Migration in Guatemala? Economic Development and Cultural Change, 41(4), 817-831.

Munshi, K. (2003). Networks in the modern economy: Mexican migrants in the U.S. labor market. Quarterly Journal of Economics, 118(2), 549-597.

National Immigration Forum (2017). Polling update: public support grows for providing legal status for undocumented immigrants. Washington, DC: National Immigration Forum. https://immigrationforum.org/article/polling-update-publicsupport-grows-providing-legal-status-undocumented-immigrants/.

Nawrotzki, R. J., Riosmena, F., \& Hunter, L. M. (2013). Do rainfall deficits predict U.S.-bound migration from rural Mexico? Evidence from the Mexican census. Population Research and Policy Review, 32(1), 129-158.

Passel, J. S., \& Cohn, D. V. (2017). As Mexican share declined, U.S. unauthorized immigrant population fell in 2015 below recession level. Washington, DC: Pew Research Center.

Passel, J. S., \& Cohn, D. V. (2018). U.S. unauthorized immigrant total dips to lowest level in a decade. Washington, DC: Pew Research Center.

Piore, M. J. (1979). Birds of passage: migrant labor in industrial societies. New York: Cambridge University Press.

Portes, A., \& Walton, J. (1981). Labor, class, and the international system. New York: Academic Press.

Portes, A., \& Zhou, M. (1993). The new second generation: segmented assimilation and its variants. Annals of the American Academy of Political and Social Science, 530, 74-96.

Ramos, M. R., Bennett, M. R., Massey, D. S., \& Hewstone, M. (2019). Humans adapt to social diversity over time. Proceedings of the National Academy of Sciences, 116(25), 12244-12249. https://doi.org/10.1073/pnas.1818884116

Reichert, J. S., \& Massey, D. S. (1982). Guestworker programs: evidence from Europe and the United States and some implications for U.S. policy. Population Research and Policy Review, 1(1), 1-17.

Robin, C. (2006). Fear: the history of a political idea. Oxford: Oxford University Press.

Sassen, S. (1988). The mobility of labor and capital: a study in international investment and labor flow. Cambridge: Cambridge University Press.

Shellman, S. M., \& Stewart, B. M. (2007). Predicting risk factors associated with forced migration: an early warning model of Haitian flight. Civil Wars, 9(2), 174-199.

Silva, C., \& Massey, D. S. (2014). Violence, networks, and international migration from Colombia. International Migration, 54(5), $162-178$.

Singer, A., \& Massey, D. S. (1998). The social process of undocumented border crossing. International Migration Review, 32, $561-592$.

Stark, O. (1991). The migration of labor. Cambridge: Basil Blackwell.

Suhrke, A. (1994). Environmental degradation and population flows. Journal of International Affairs, 47, 473-496.

Tacoli, C. (2019). Crisis or adaptation? Migration and climate change in a context of high mobility. Environment \& Urbanization, 21(2), 513-525.

Taylor, J. E. (1986). Differential migration, networks, information and risk. In O. Stark (Ed.), Migration theory, human capital and development (pp. 147-171). Greenwich: JAI Press.

Timmer, A. S., \& Williamson, J. G. (1998). Immigration policy prior to the 1930s: labor markets, policy interactions, and globalization backlash. Population and Development Review, 24, 739-772.

Todaro, M. P. (1976). Internal Migration in Developing Countries. Geneva: International Labor Office.

U.N. High Commissioner on Refugees (2019). UNHCR population statistics database. New York: United Nations. http://popstats. unhcr.org/en/overview\#_ga=2.115256135.1928179598.1557238108-339991216.1555417139.

U.S. Census Bureau (2017). National population projection tables. Washington, DC: U.S. Census Bureau. https://www.census, gov/data/tables/2017/demo/popproj/2017-summary-tables.html.

U.S. Customs and Border Protection (2018). U.S. border patrol southwest border deaths by fiscal year. Washington, DC: U.S. Customs and Border Protection. https://www.cbp.gov/sites/default/files/assets/documents/2017-Dec/BP\%20Southwest\%2 0Border\%20Sector\%20Deaths\%20FY1998\%20-\%20FY2017.pdf.

U.S. Customs and Border Protection (2019). Stats and summaries. Washington, DC: U.S. Customs and Border Protection. https://www.cbp.gov/newsroom/mediaresources/stats.

U.S. Department of Homeland Security (2020). Statistical Yearbook of Immigration Statistics 1996-2018. Washington, DC: Office of Immigration Statistics, U.S. Department of Homeland Security. https://www.dhs.gov/immigration-statistics/yearbook.

Wasem, R. E. (2011). Unauthorized aliens residing in the United States: estimates since 1986. Washington, DC: Congressional Research Service.

Wolf, S. (2012). Mara Salvatrucha: the most dangerous street gang in the Americas? Latin American Politics and Society, 54(1), 65-99.

World Bank (2019). World Bank data. "International Migration Stock, total." Washington, DC: World Bank. https://data. worldbank.org/indicator/SM.POP.TOTL.

\section{Publisher's Note}

Springer Nature remains neutral with regard to jurisdictional claims in published maps and institutional affiliations. 